Arch. histol. jap. Vol. 29, No. 4 (1968) p. $399-424$

Department of Physiology (Prof. K. Uchizono), Faculty of Medicine, University of Tokyo, Bunkyo-ku, Tokyo, Japan

\title{
Axon Identification in the Cerebellar Cortex of the Cat
}

\author{
Koji Uahizono（内 薗 耕二) \\ Received June 12, 1968
}

Remarkable progress has been brought about in the study of the cerebellar cortex. Functional analysis of the neuronal elements in this region of the CNS has been done in detail in conjunction with electron microscopic investigations. The recently published monograph on the cerebellum by Eccles, Itoh, and SzentágoTHAI (1967) has shed light on the study of this rather neglected area of the CNS. Neurons, interneurons and axons have been analyzed in detail and identified on the combined grounds of ultrastructure and electrophysiology. The architectural design of the cerebellar cortex has been brought to the utmost clarity owing to the strenuous efforts of many workers in this field; among others, Szentágothal and his associates have contributed most to the study of the cerebellar structure. The efferent and afferent fiber connections were well analyzed on the ground of the findings of light and electron microscopy. The well designed degeneration experiments of HAMORI (1964) and SzentáGothai (1965) have much clarified the situation which had remained ambiguous so far. Functional analysis has been done electrophysiologically with brilliant success by Ecales (1965), Ecales and his associates (1964, 1966 a, b, c). The excitatory and inhibitory nature of each neuron in this complicated nervous system has been proposed on the basis of the analysis of electrical events of neurons. A new hypothesis has been proposed by the present author which enables us to distinguish excitatory and inhibitory synapses morphologically (Uchizono 1965, 1966, 1967 a, b). This paper concerns mostly with the axon identification based on S- and F-type synapse (Uchizono, 1965, 1966, 1967 a, b) in the cerebellar cortex.

\section{Materials and Methods}

Cats were anesthetized by an intraperitoneal injection of Nembutal $30 \mathrm{mg} / \mathrm{kg}$. After complete perfusion with Locke's solution through the cannula inserted into the ascending aorta as originally reported by PALAY et al., the whole body of the animal was fixed with formaldehyde solution buffered at 7.4 by Millonig's phosphate buffer. The skull of the animal was opened and slices of the cerebellar cortex were prepared for the post-fixation with osmium-tetroxide solution. Dehydration, embedding and sectioning were carried out routinely. After double staining with lead hydroxide and uranyl acetate solutions, electron microscopic investigations were carried out by an Akashi TRS 80 electron microscope. A strip-mesh was used for obtaining as large sections as possible of the cortex which facilitated getting large survey electron micrographs of the molecular layer of the cerebellum. A big montage-picture was made from about 20 electron micrographs taken at a relatively low magnification, which covered the large area of the cortex from the upper molecular to the granule cell layer. 


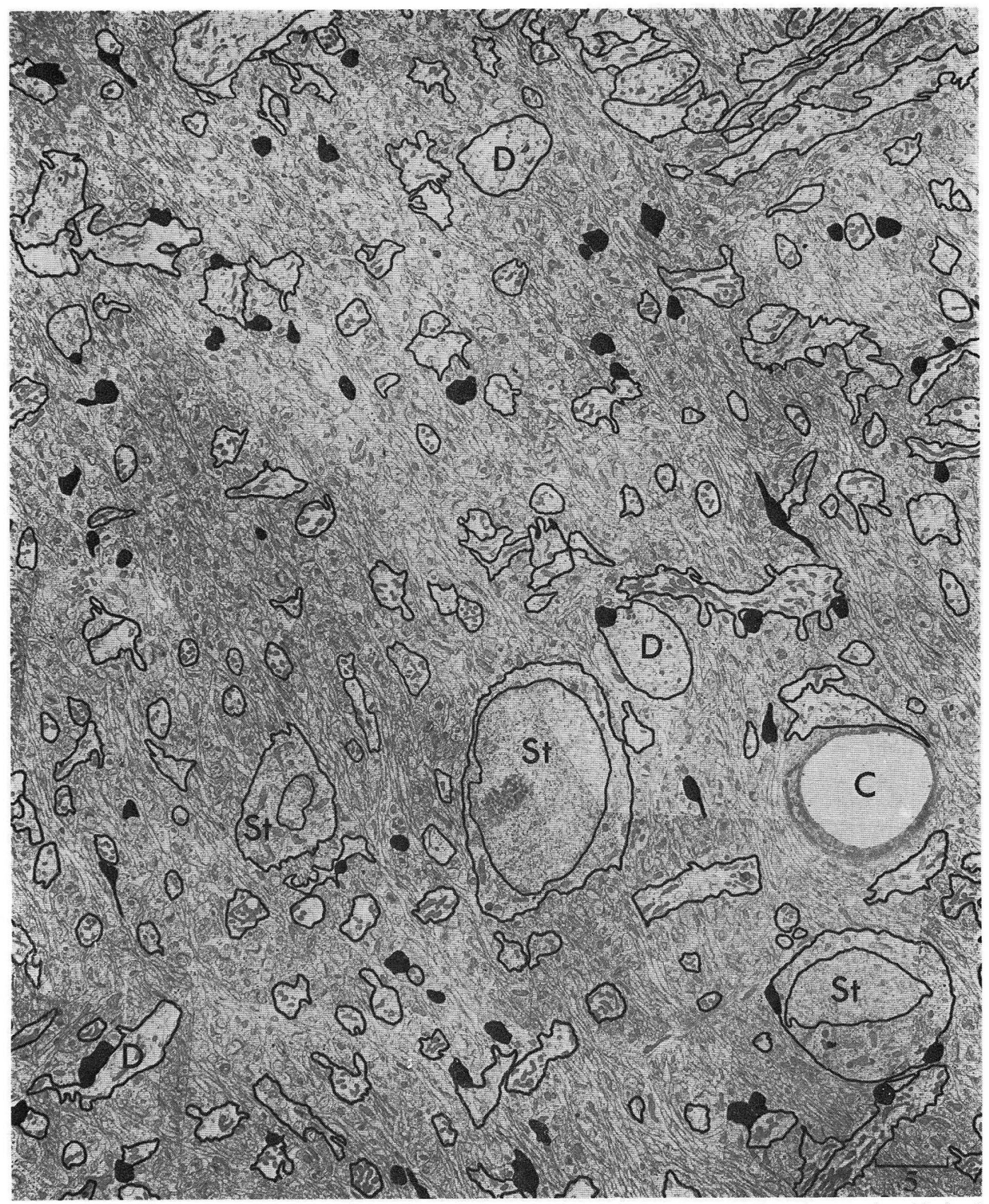

Fig. 1. Montaged electron micrograph of the upper molecular laycr. Rctouched outlines show various kinds of dendrites and three stellate cells $(S t)$. Black areas represent synapses which contain flattened vesicles (F-type). 


\section{Observations}

A montage picture as shown in Figure 1 was useful in finding the location of the neurons under study. Information obtained from the literature on classical light microscopic investigations was used for the sake of orientation of the neuronal elements.

Purkinje cell axons: As reported by Hamori and Szentágothai (1965) the initial part of the Purkinje cell axon looks more like an elongated part of the cell body because it contained not only neurofilaments but also an endoplasmic reticulum and numerous ribosomes that usually are absent in axons. In Figure 2 a true axon of the Purkinje cell is shown. This has quite the same structure as has been recently reported by HAMORI and Szentágothai (1967). This structure was first described by AndRes (1965). The myelinated fibers of the cerebellar cortex are thought to be specific for the Purkinje axons. They occur not only in the main axon but also in its collaterals and even in their terminals. Mugnaini et al. (1967) also reported the same type of myelinated axon in the Deiters' nucleus. This puzzling structure may be taken as a criterion for the axon of the Purkinje cell, but it must be kept in mind that only a small part of the Purkinje axons contains this peculiar structure; consequently chances are extremely limited to encounter this remarkable structure under the electron microscope. A small thin myelinated axon was of ten seen to run together with the big thick myelinated fiber (Fig. 3). The former was presumed to be an axon collateral of the Purkinje cell axon, while the latter was presumed to be a main Purkinje axon. Thin myelinated nerve fibers of the same type were often encountered high up in the molecular layer which showed well developed neurofilaments (Fig.3-B). It was shown in a longitudinal section that this type of myelinated nerve made a $\mathrm{F}$. type synapse on the probable Purkinje cell dendrite (Fig. 4). On the other hand, the inhibitory nature of the Purkinje cell has been well established electrophysiologically by Ітон and his associates $(1964,1966)$. Classical light microscopy indicates that the myelinated axons in the ganglionic plexuses of the cerebellar cortex originate from the Purkinje cells. These axon collaterals of the Purkinje cells are generally supposed to terminate on the principal dendrites of the Purkinje cell ( $\mathrm{C}_{\mathrm{AJAL}}$, 1911). The F-type synapse in Figure 4-A which indicates clearly the inhibitory nature of this axon, however, is situated not on the principal dendrite but on a small dendrite. Usually the myelinated axon makes its synapses on a post-synaptic structure at the point where it becomes deprived of its myelin sheath. This is the case with the mossy fibers which make excitatory synapses in the cerebellar glomeruli (see below).

In Figure 4-B cross-sections of myelinated and non-myelinated small nerves in the supraganglionic plexus are shown. One of the myelinated fibers contains a peculiar structure composed of a regularly spaced tubular system with dense matrix in the axoplasm. It was assumed that this strange fiber together with the other myelinated nerves are also axon collaterals of the Purkinje cell axons. It was suggested by CAJAL (1911) that the Purkinje axon collaterals make synapses on the soma of the Purkinje cells. Figure 5 shows thin myelinated nerve fibers in the vicinity of the Purkinje cell soma. It was often demonstrated that some of these fibers make close contact with the Purkinje cell, although it was not always successful in identifying these nerve terminals as making true synapses on the Purkinje cell soma. Usually 
A

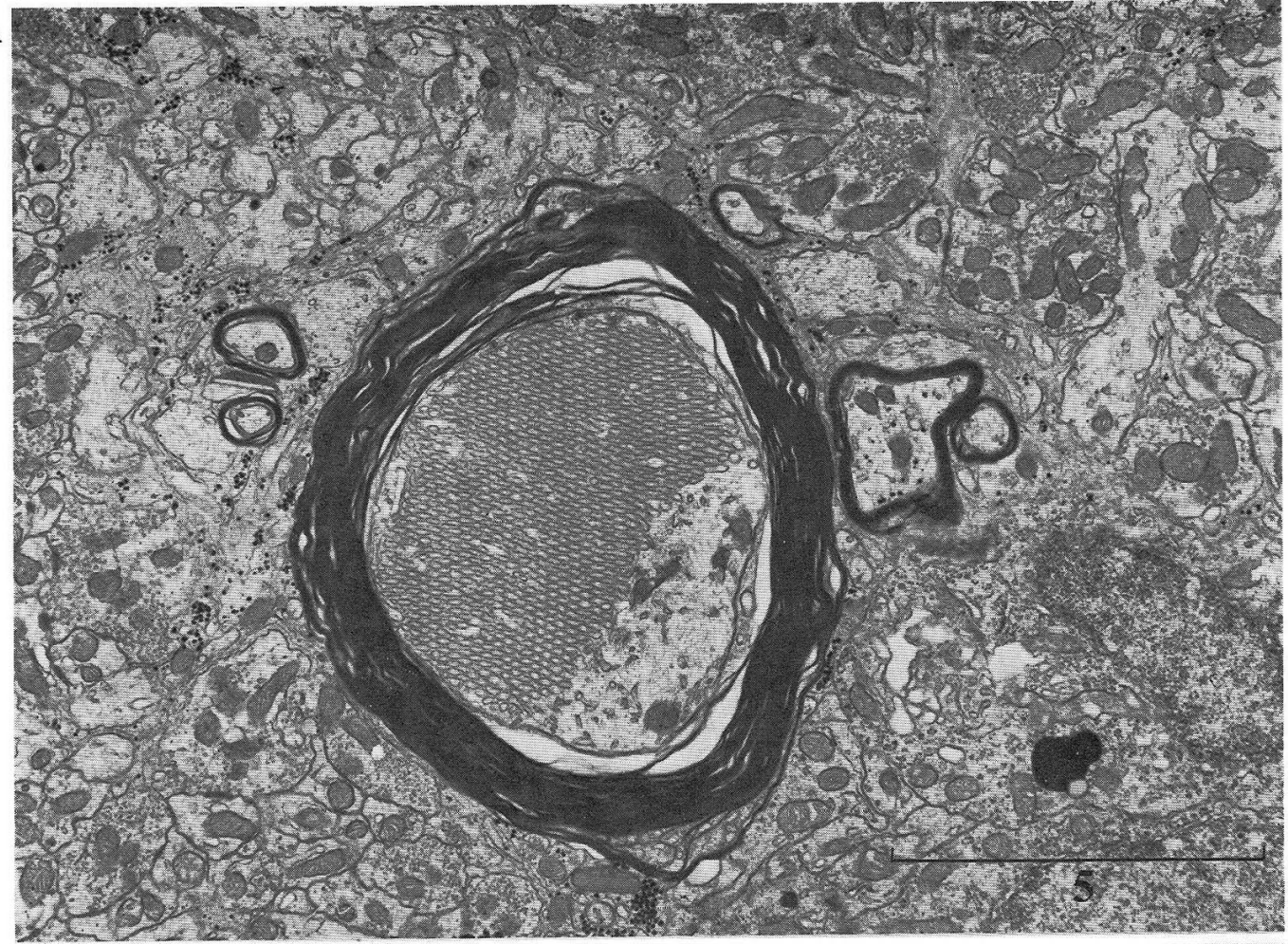

B

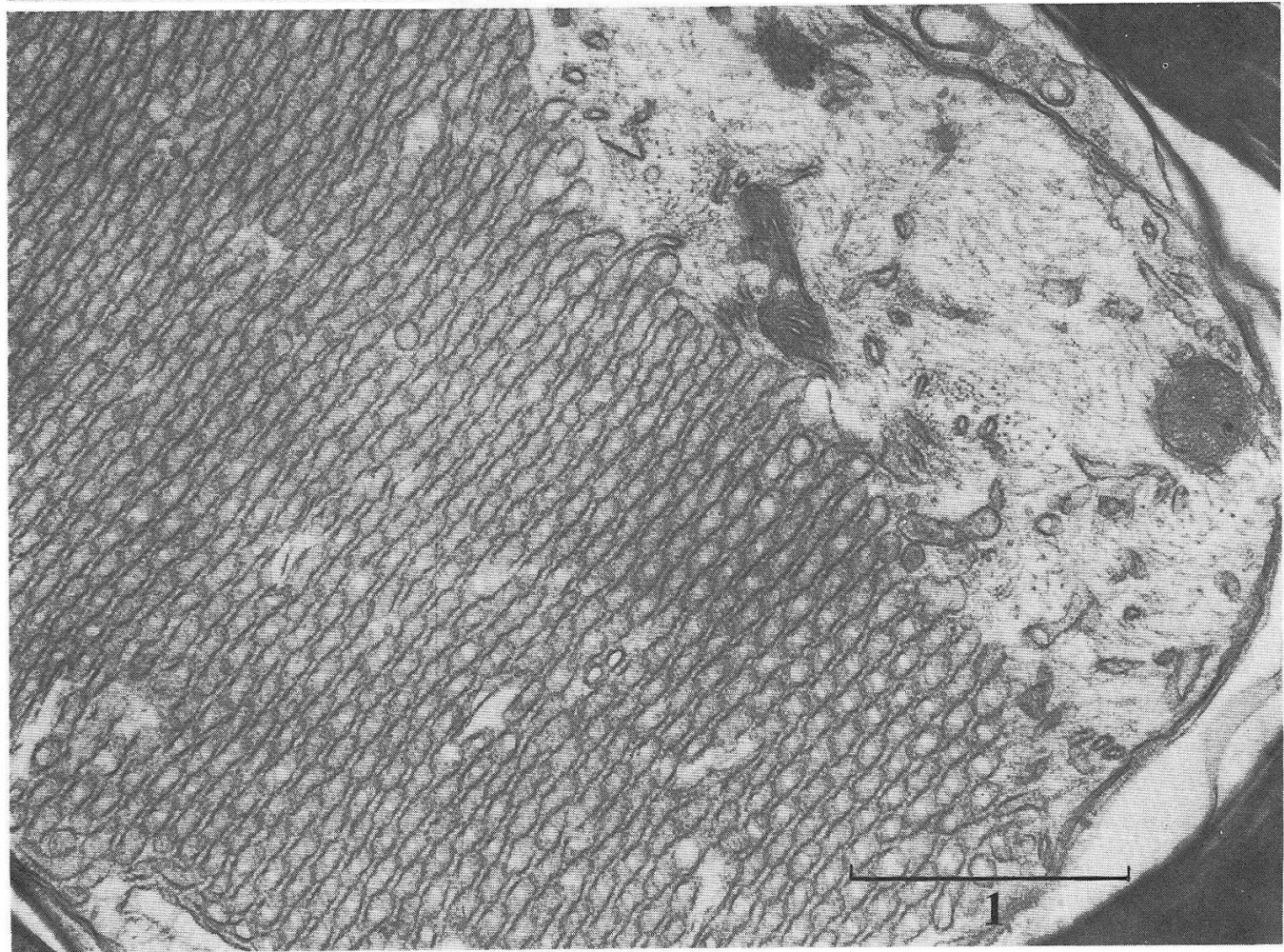

Fig. 2. For legend see p. 406. 
Axon Identification in the Cerebellar Cortex of the Cat

403

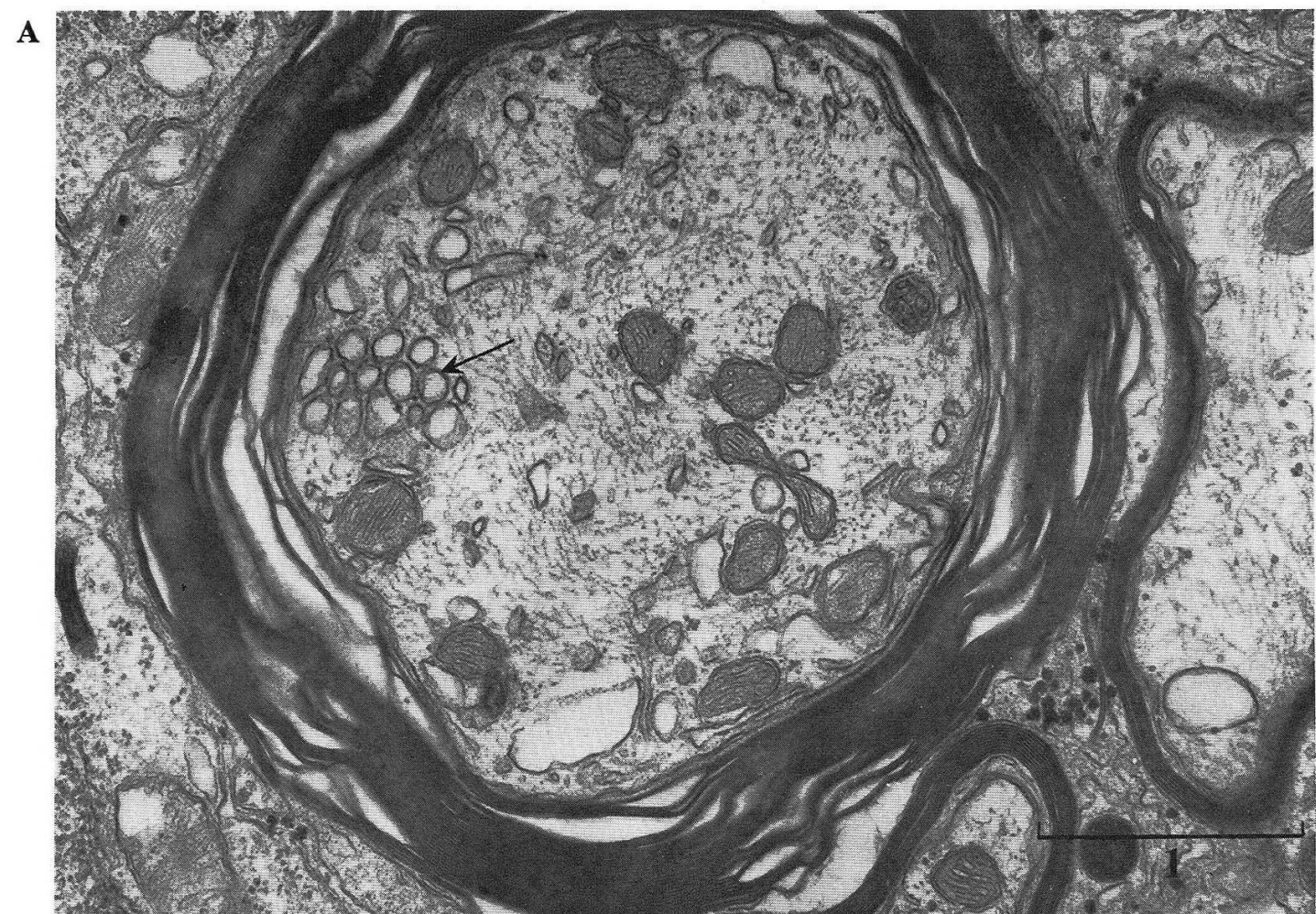

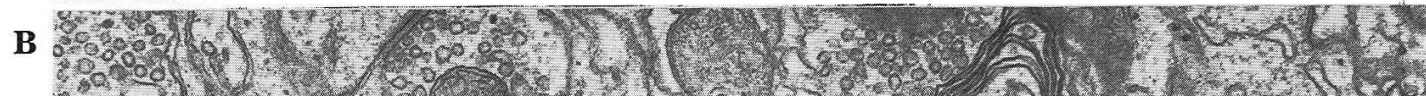

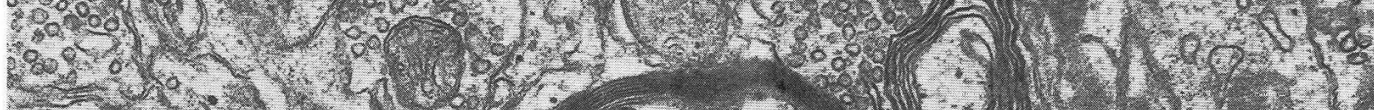

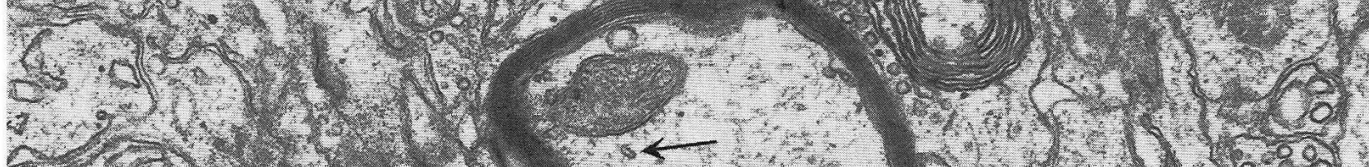

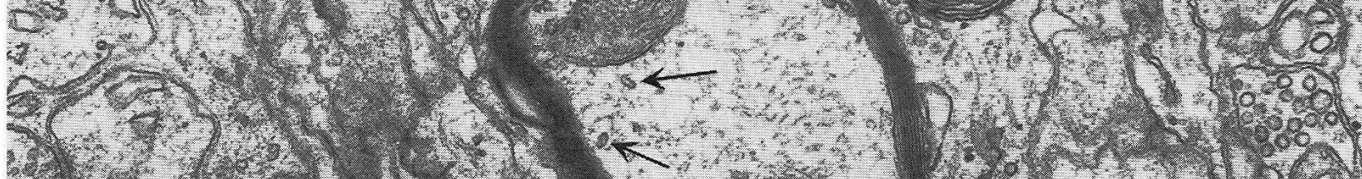

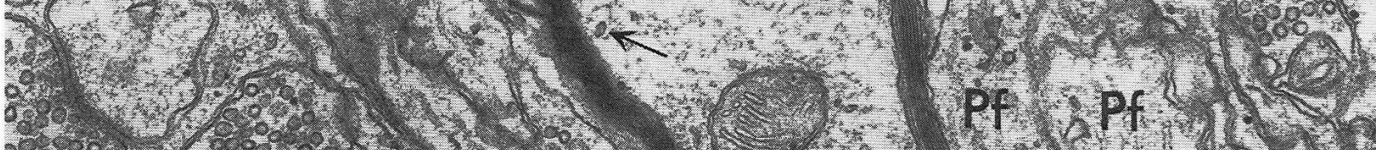

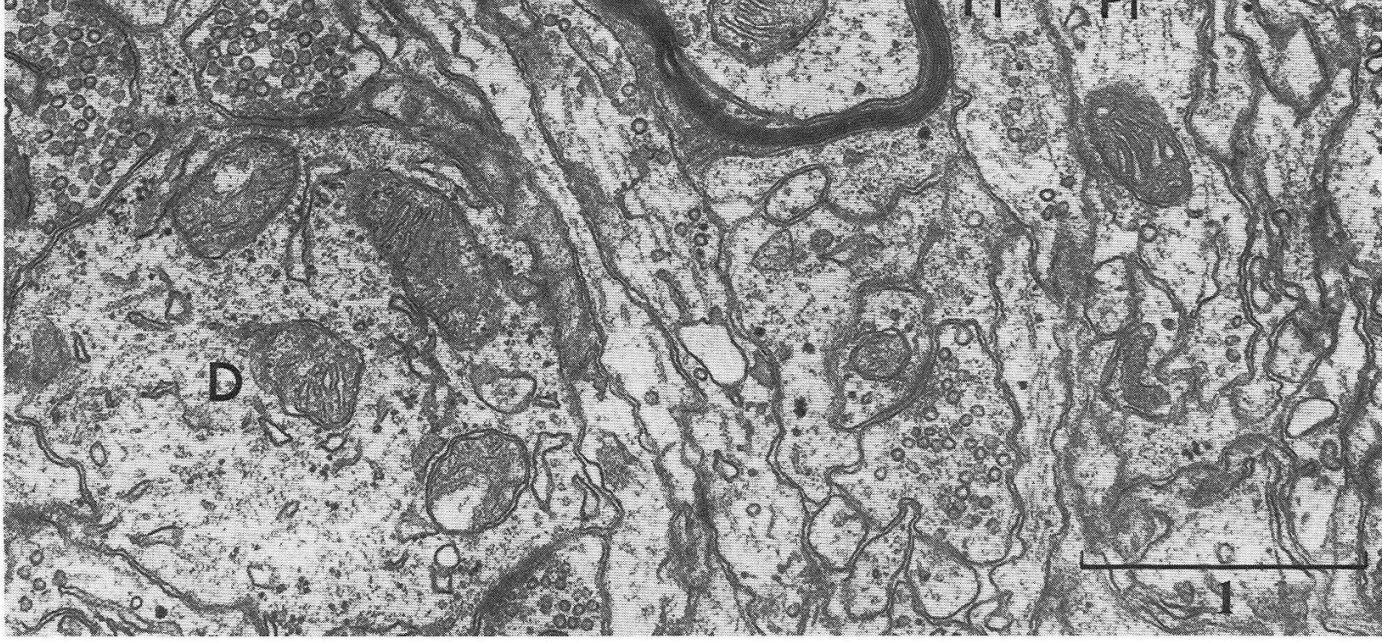

Fig. 3. For legend see p. 406. 
A

$\cos ^{-3}$

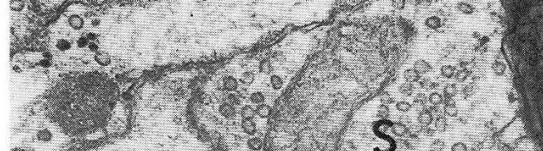

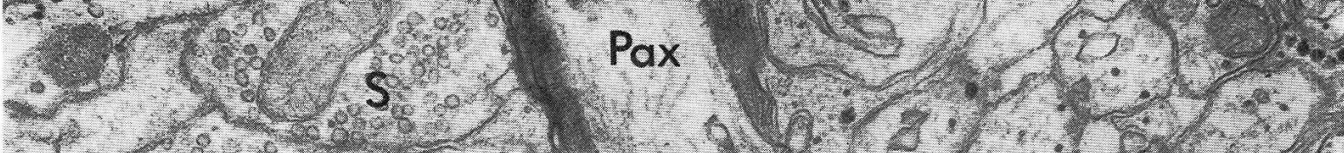

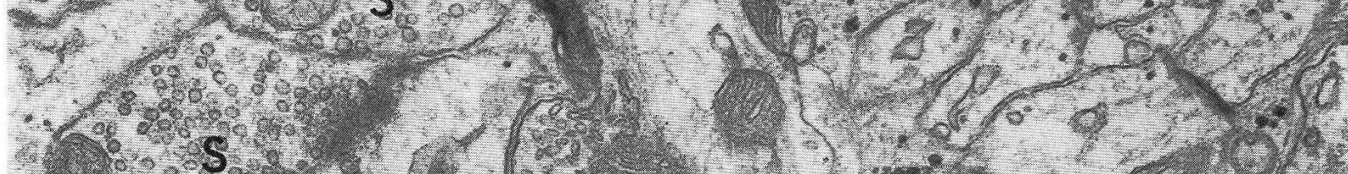

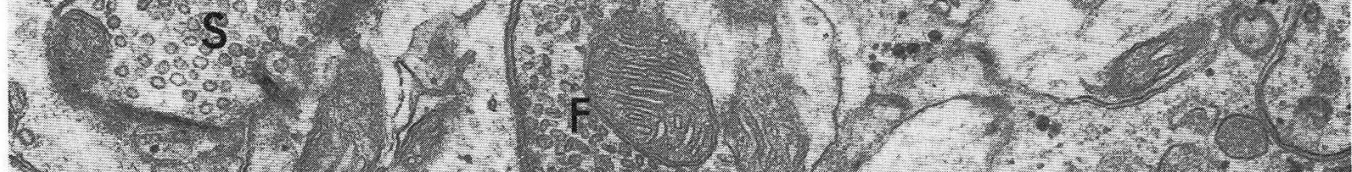

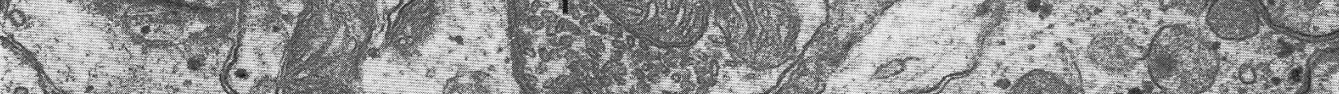

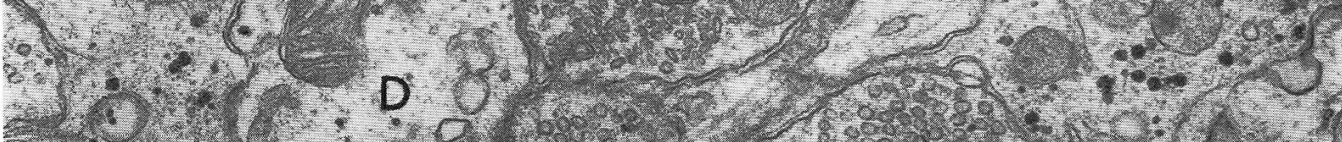

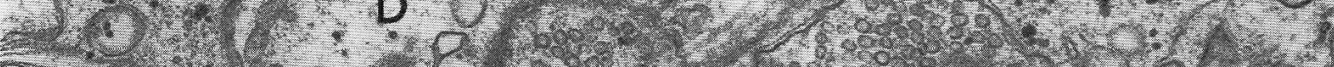

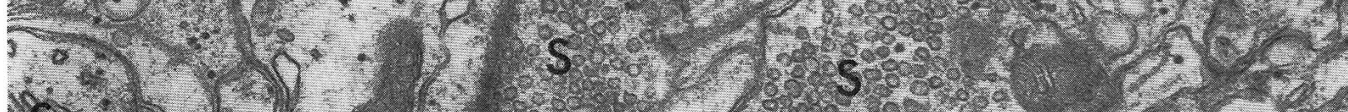
Sp.

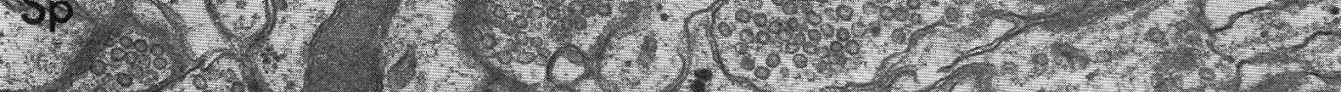

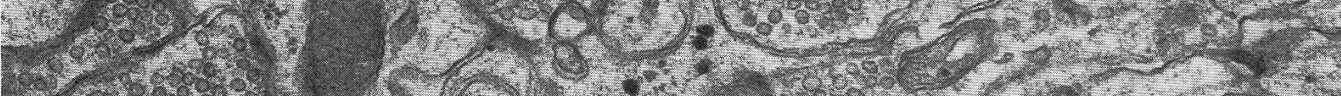

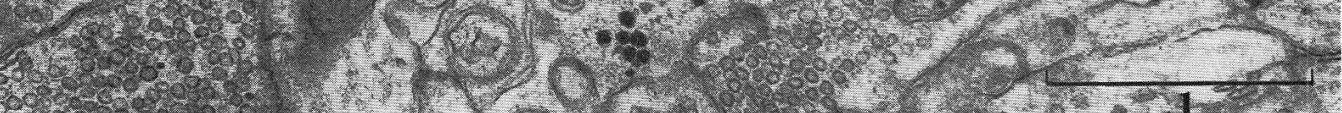

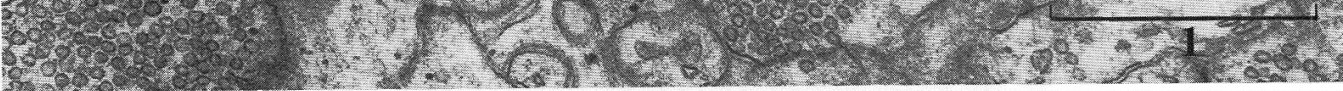

B

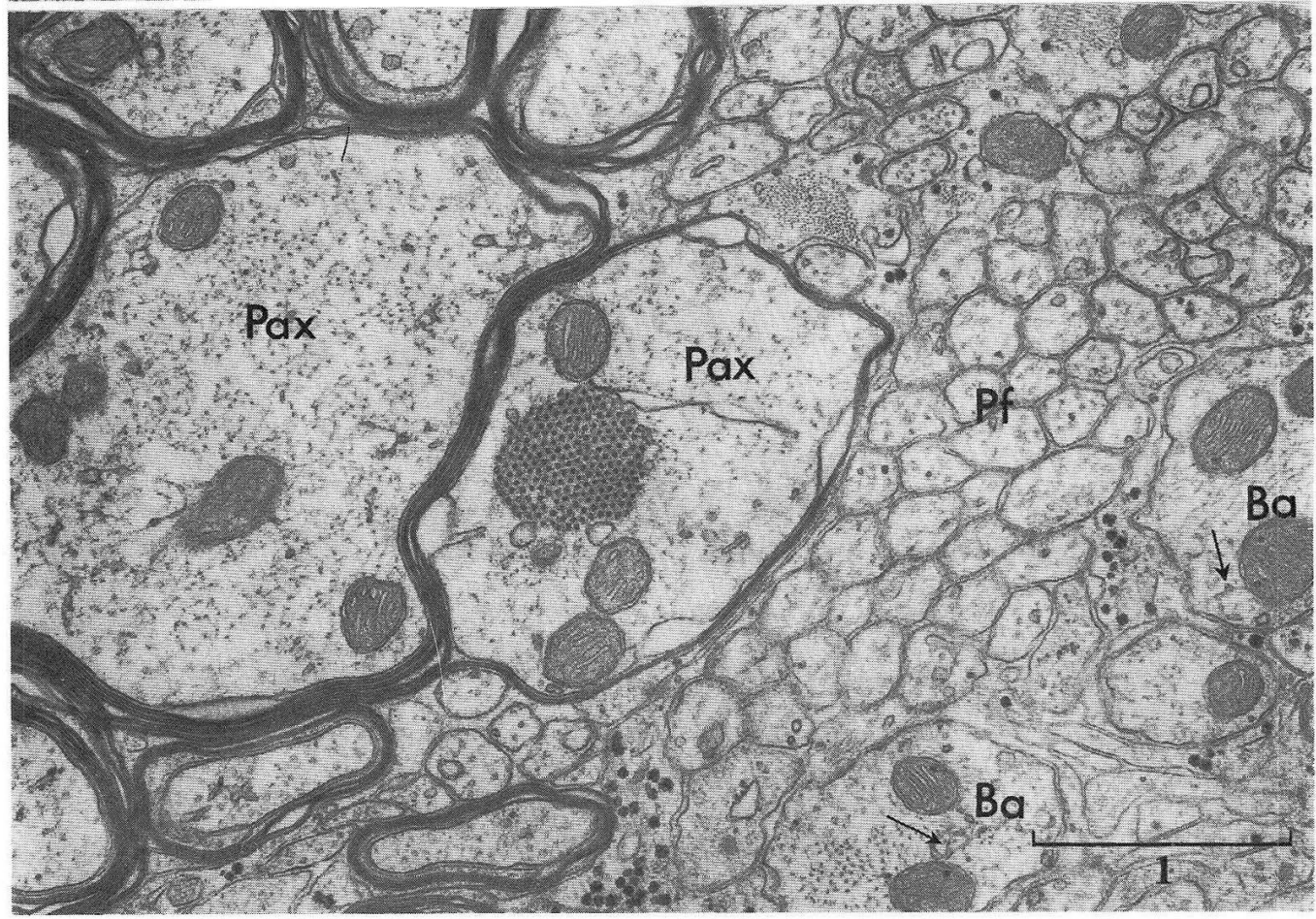

Fig. 4. For legend see p. 406. 
A

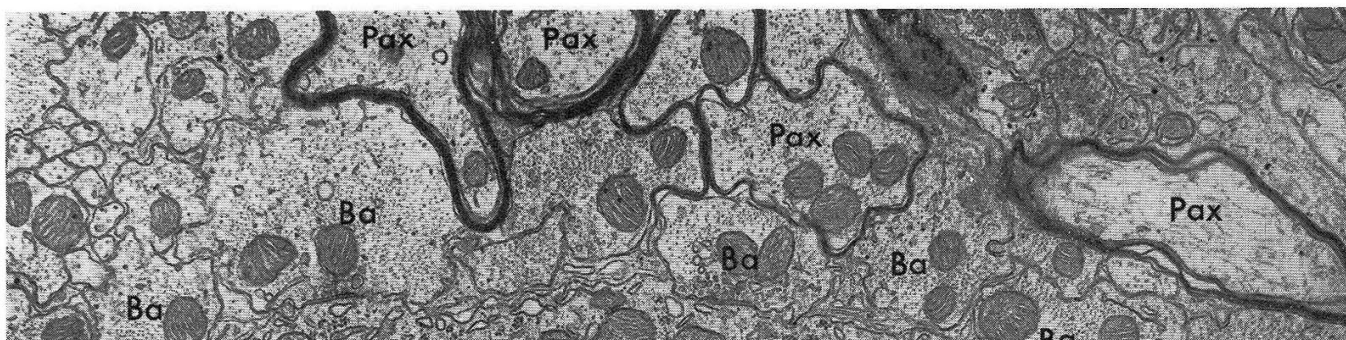

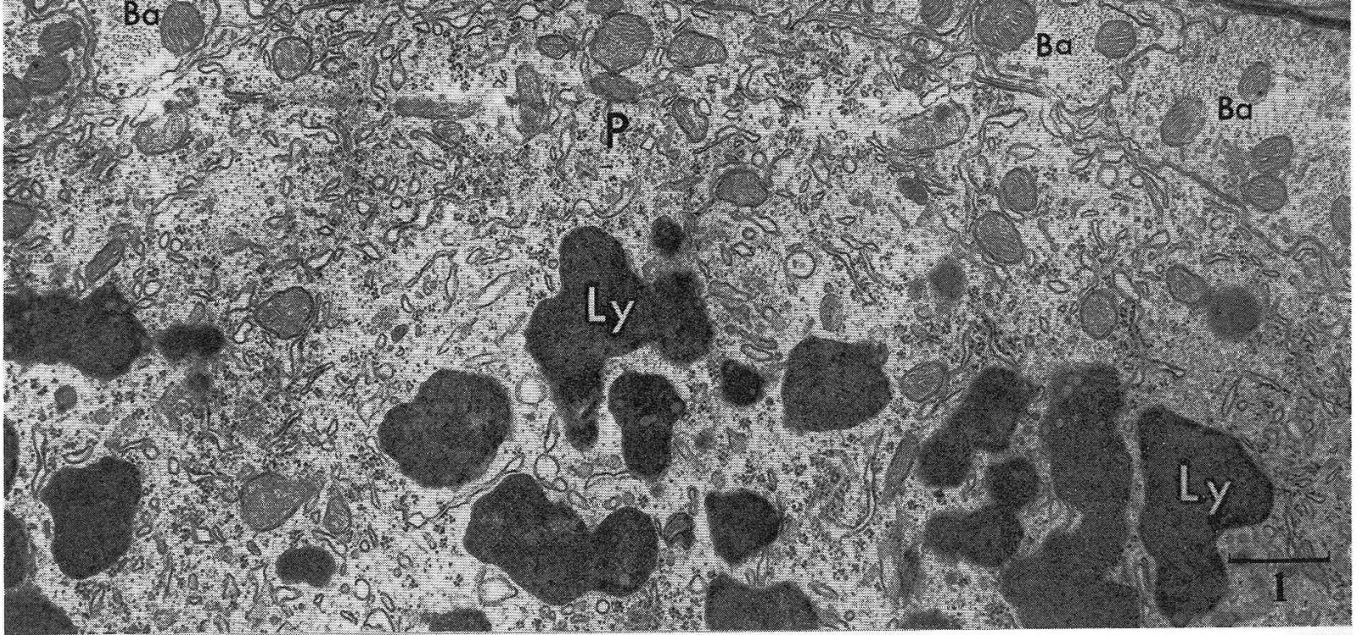

B

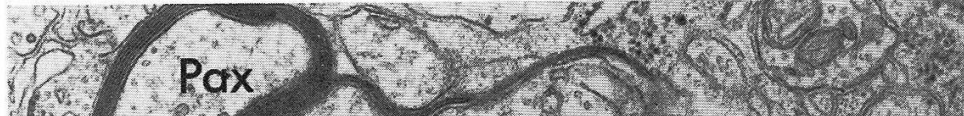

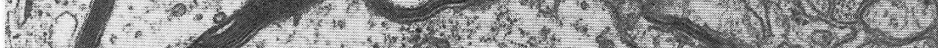

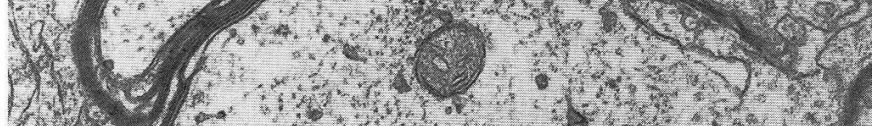

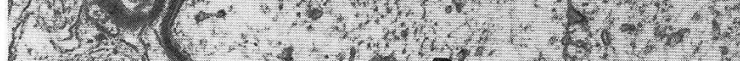

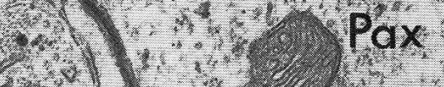
$28)^{2}$

23

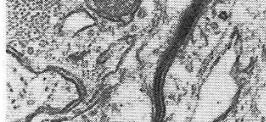

$\operatorname{los} 2$
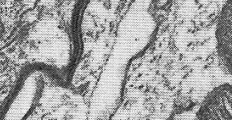

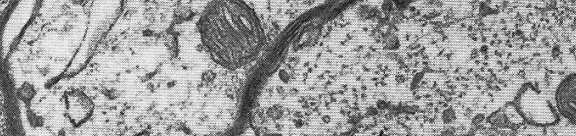

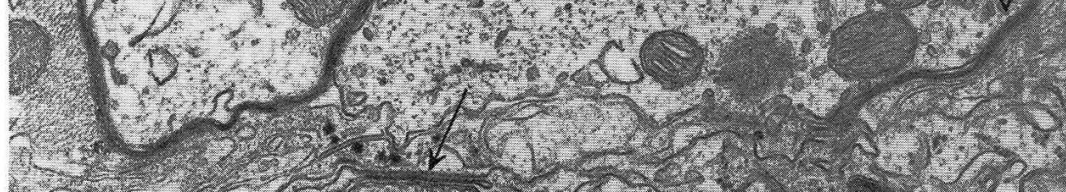

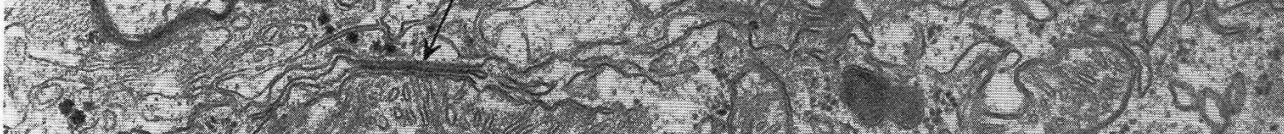

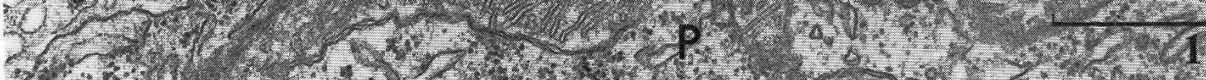

Fig. 5. For legend see p. 406. 
basket cell axons are non-myelinated, therefore these thin myelinated axons which have well developed neurofilaments without membraneous bodies may originate from Purkinje cells. It was, however, difficult to discern two inhibitory inputs to the surface of the Purkinje cell soma, the one from basket cells, the other from Purkinje axon collaterals.

Light microscopy suggests that the main axons of the basket cells get thicker after emerging from the axon hillock as in the case with the Purkinje cell axons. Therefore, it might be possible that these thicker parts of the basket cell axons are myelinated. Consequently one possibility remains that the thin myelinated axons in the vicinity of the Purkinje cells may originate from the basket cells.

Parallel fibers : It has been well established that the granule cells give off a formidable number of $\mathrm{T}$-shape parallel fibers vertically and horizontally. It was shown by Hamori and Szentágothai (1966) that these parallel fibers make "crossing-over" synapses on the spines of various kinds of neurons in the molecular layer of the cerebellum. The diameter of the parallel fibers are far smaller than that of the crossing-over synapses (Fig.6). A single parallel fiber bulges repeatedly to make synapses at various sites along its course. Many vesicular structures, irregular in size and shape, are seen in the axoplasm in both vertical and horizontal parts of the fibers, which may suggest the precursors of synaptic vesicles at the axon termi-

Fig. 2. Purinkeje cell axon

A : A relatively large myelinated axon (more than $5 \mu$ in diameter) in the granule cell layer of the cerebellum which is thought to be the main axon of the Purkinje cell. Some thin myelinated axons are also indicated. These axons are embedded in the cerebellar glomeruli. B : Strange lamellar structure with $0.1 \mu$ periodicity in the axoplasm of a Purkinje axon. About one fourth of the axoplasm is clear and is filled with neurofilaments, mitochondria and endoplasmic reticulum.

Fig. 3. A : A thick myelinated axon in the granule layer. The axoplasm is filled with neurofilaments, mitochondria, endoplasmic reticulum and a cluster of vacuoles (see arrow). The axoplasm looks like a clear zone in Figure 2-B. A small axon in parallel with this fiber is seen at right.

B : A small axon with thin myelin is seen among the parallel fibers and their synapses. A couple of flattened vesicles are indicated (arrows) in the axoplasm which is rich in neurofilaments. $D$ dendrite, $P f$ parallel fiber.

Fig. 4. A : A small myelinated axon (less than $1 \mu$ in diameter) which makes a F-type synapse at the node of Ranvier in the upper molecular layer of the cerebellar cortex. $D$ dendrite, Pax possible Purkinje axon collateral, $S$ S-type synapse, $S p$ spine, $F$ F-type synapse.

B : Thinly myelinated axons in the supraganglionic plexus. They are rich in neurofilaments. Regularly spaced tubular structures are shown in the axoplasm of an axon (center). Abundant cross-sections of parallel unmyelinated fibers are seen in the right. Probable basket axons with characteristic neurofilaments and membraneous structures (arrows) are seen at the lower right. Pax Purkinje axon collaterals, $P f$ parallel fibers, $B a$ basket cell axons.

Fig. 5. A : Several thin myelinated axons in the vicinity of a Purkinje cell soma are seen over-lying the basket axon synapses. The former are suspected of Purkinje cell axon collaterals and are rich in neurofilaments. Cross-section of the basket axons which contain flattened vesicles are seen to make synaptic contacts with the Purkinje cell soma. $P$ peripheral part of the Purkinje cell soma which contains abundant lysosomes $(L y)$. Pax Purkinje axon collaterals, $B a$ basket axon terminals

B : Purkinje axon collaterals ( $P a x)$ making synaptic contact directly with the soma of Purkinje cell $(P)$. A small myelinated axon which contains flattened vesicles (white arrow) in the axoplasm is shown. Subsurface cystern is indicated by an arrow. 
nals, because the concentration of these vesicular structures increases toward the synaptic sites. This is also suggestive of an axonal flow of synaptic vesicles in immature forms. Sometimes bead-like structures were seen as shown in Figure 6-B. Crossing-over synapses contain spheroid vesicles, indicating the excitatory nature of the granule cells.

All kinds of dendrites in the molecular layer are innervated by parallel axons which originate from the granule cells. No parallel fiber inputs to the surface of the Purkinje cell soma was postulated, because the latter is exclusively innervated by Ftype synapses as has been identified by the present author (UCHIzono 1965, 1966, 1967). No parallel fiber innervation to the Golgi cell soma was postulated, because no horizontal component of granule cell axons was observed on it. Excitatory inputs to the Golgi cell soma may originate only from climbing fibers as postulated by SaHEIBEL and Scheibel (1954), although at that time Purkinje cell axon collaterals were also suspected as the same type of input to the Golgi cell soma with the same probability. The Purkinje cell is today well established as an inhibitory neuron by Iтон and his associates (1964).

Some of the S-type synapses on the surface of basket cells were supposed to originate from the climbing fibers, although the other S-type synapses there may originate from the parallel fibers, which have been elucidated by Eacles and his associates (1964) to be excitatory in function. Morphological evidence of the excitatory nature of granule cells was deduced from the fact that this type of synapse contains spheroid vesicles, characteristic of the excitatory nature of synapses as has been proposed by the present auther (Uahizono 1965, 1966, 1967).

Upper stellate cell axons : In spite of the ample light microscopic informations on the fiber connection of the upper stellate cells, identification of the axons and synapses of these neurons under the electron microscope was rather difficult. On the basis of the ramification pattern of these axons, two main upper stellate cell types, type a and type b, can be distinguished under the light microscope. Unfortunately we have no criteria for the identification of stellate cell axons under the electron microscope. In a luckey section a short axon which emerged from a stellate cell dendrite was once observed by the present author (in preparation), and furthermore it was confirmed that a F-type synapse of this axon was made on the dendrite in the molecular layer of the cerebellum, although no evidence was obtained as to which neuron this dendrite belonged. This is a clear evidence that the stellate cell is inhibitory in function. Under the light microscope the descending branches of the upper stellate cells can be traced to the bottle neck of the Purkinje cells, but not deeper into the basket. Electron microscopic investigations indicated that large Ftype synapses were made on the direct surface of the primary or secondary dendrite of Purkinje cells, therefore it was assumed that these synapses might originate from the upper stellate cells. This assumption, however, is fortuitous, because there are two other alternatives. Two inhibitory inputs to the primary dendrites of the Purkinje cells are known: Purkinje axon collaterals and branches of basket cell axons. It was observed that only 5 percent of synapses (out of about 2000 synapses) were of F-type, while 95 percent were S-type in the upper molecular layer of the cerebellum. The inhibitory synapses of the stellate axon may contribute to this minority group of 
K. Uchizono :

A

408

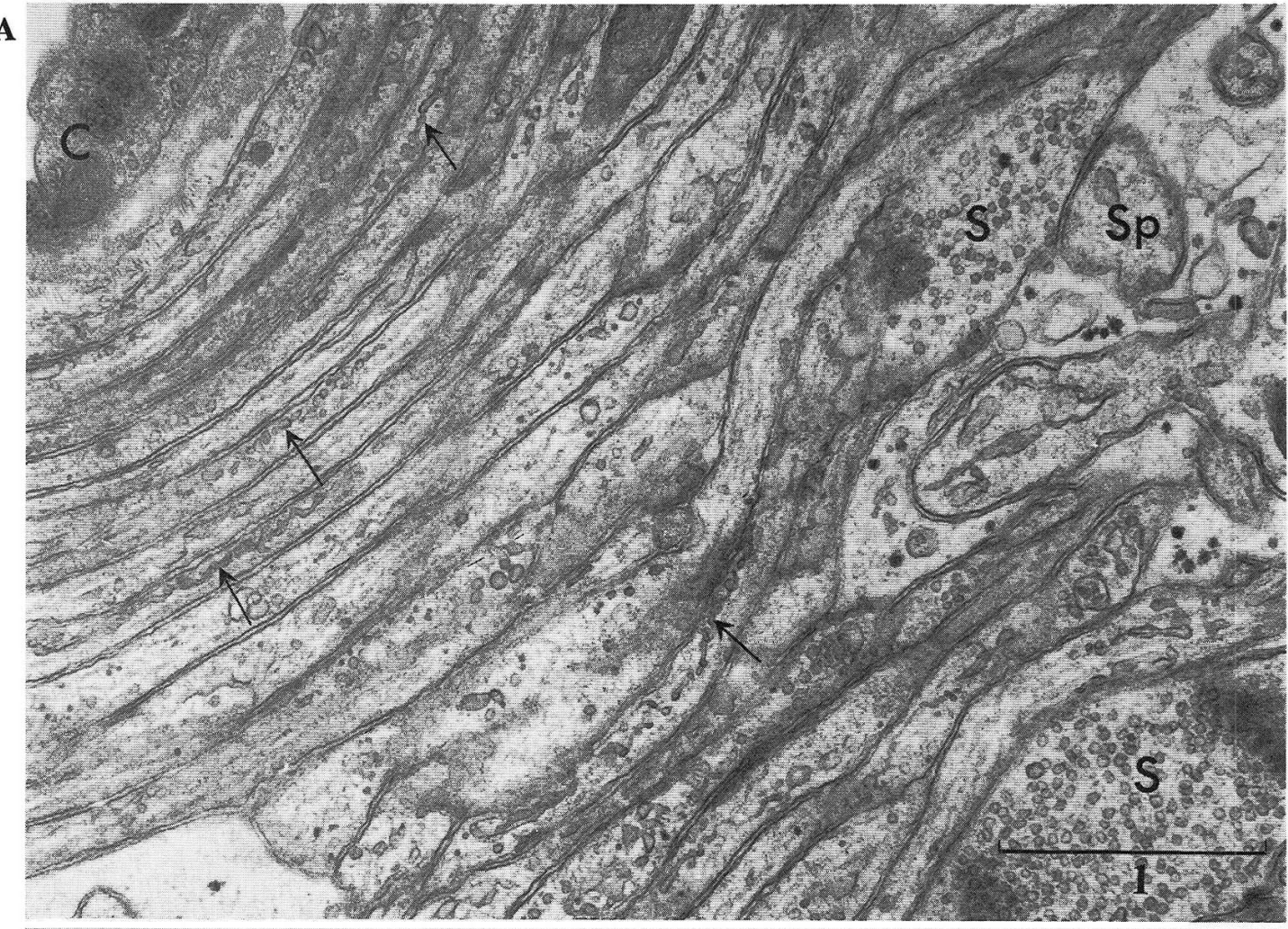

B

$-1+\cos ^{2} \omega^{2}$

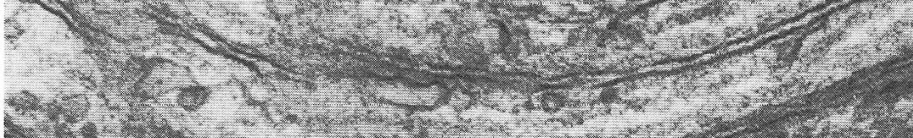

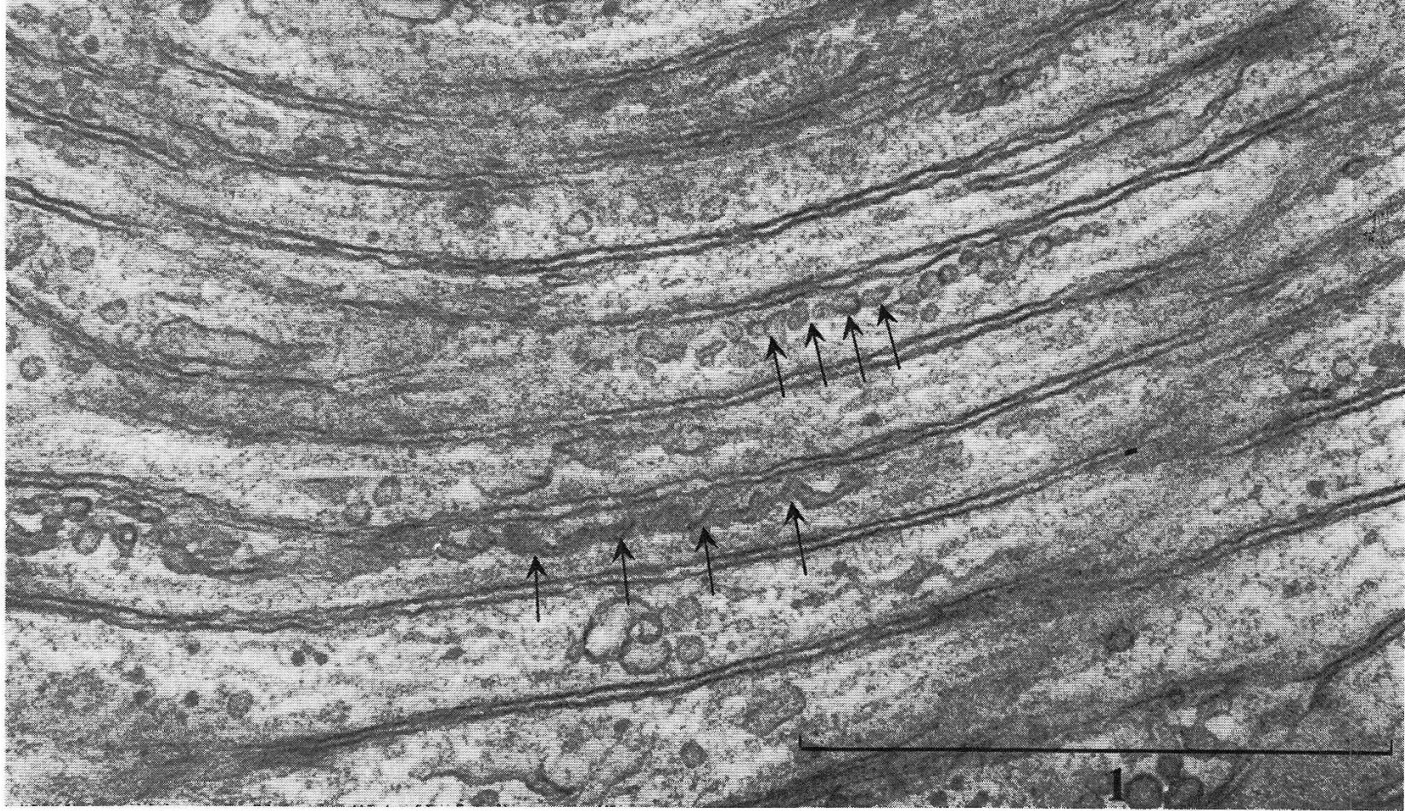

Fig. 6. For legend see p. 410. 
Axon Identification in the Cerebellar Cortex of the Cat

409

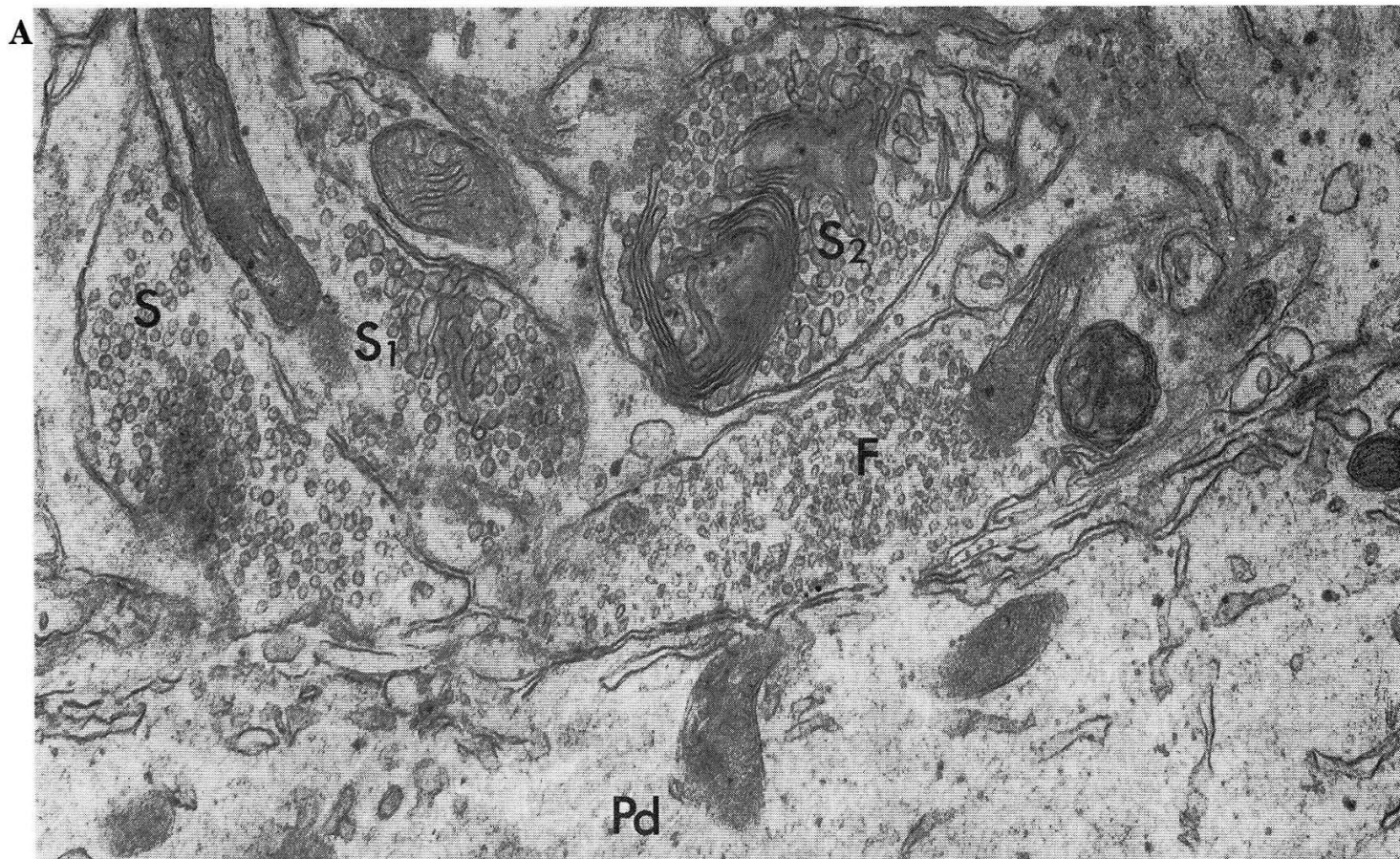

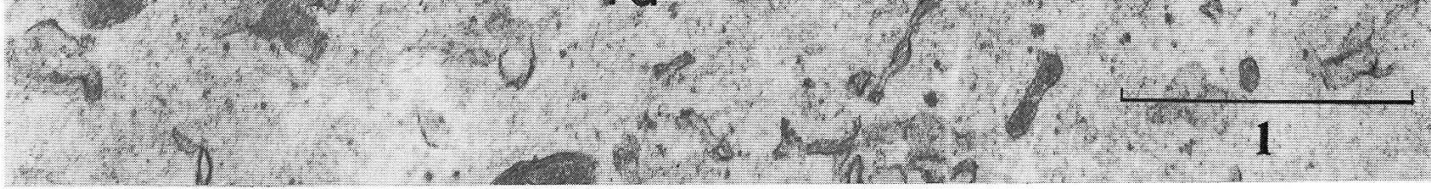

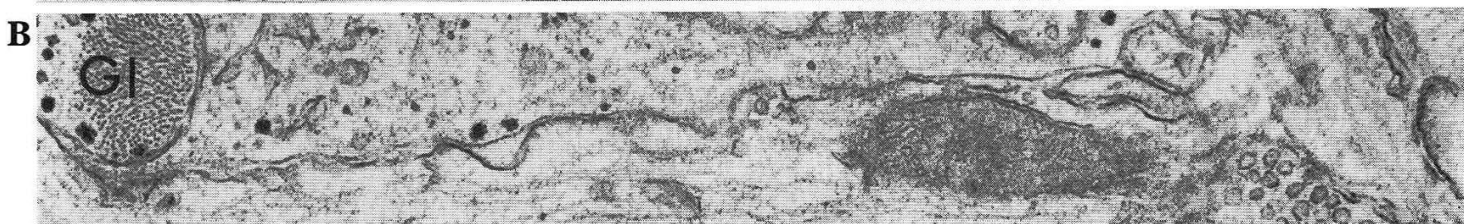

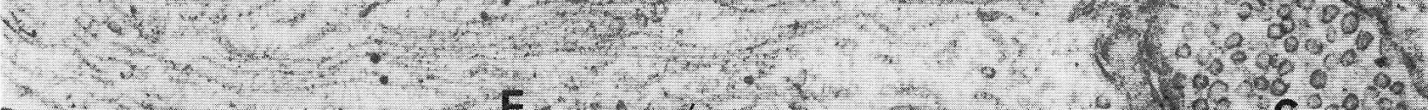
H. n:

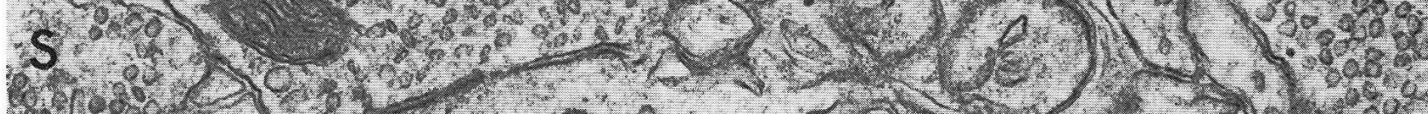

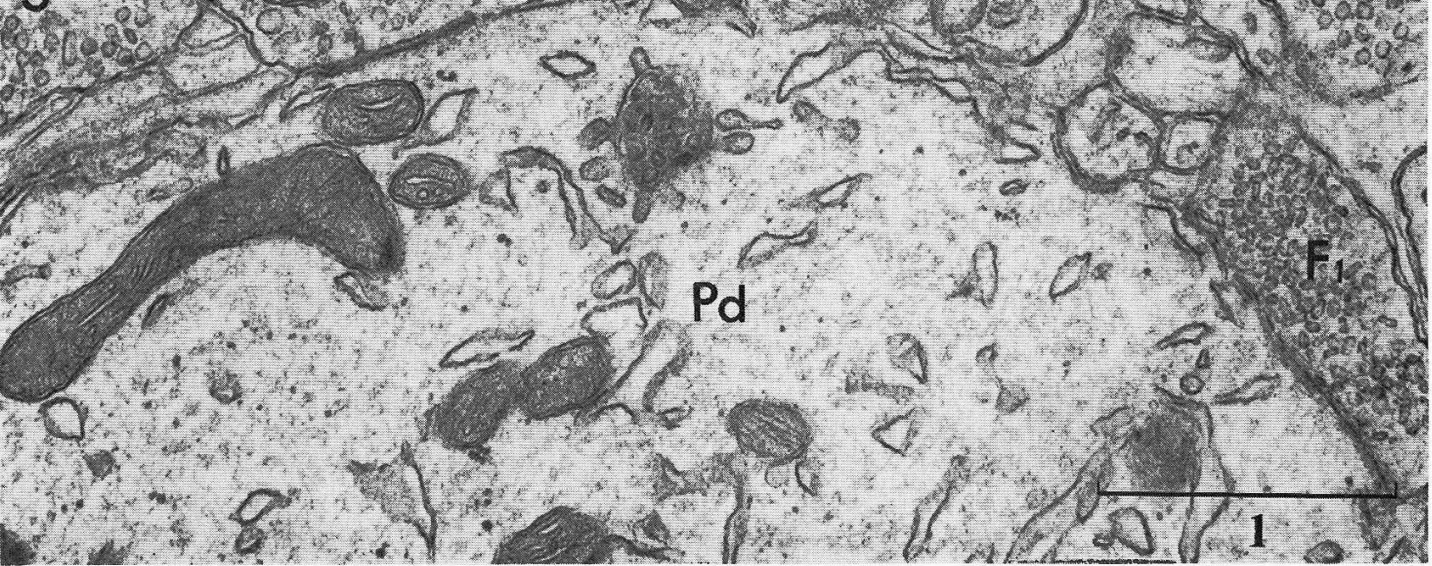

Fig. 7. For legend see p. 410. 
F-type synapses. Figure 7 shows a possible candidate for the stellate cell synapse made on the bottle neck of the Purkinje cell.

Basket cell axons: These axons were rather easily identified owing to their remarkable characteristics; well developed neurofilaments, strange membraneous bodies described by Hamori and Szentágothai (1965), and flattened synaptic vesicles, although rather small in number, accumulated on the synaptic sites. Identification of basket cell axons was eased by these three cardinal characteristics of axon terminals.

Figure 8 indicates typical basket cell axons in the supraganglionic plexus of the cerebellum. The direction of fiber course is perpendicular to the parallel fibers, of which cross-sections and synapses are shown. Filamentous characteristics of the axoplasm of basket cell is well demonstrated. Some membraneous bodies are scattered in the axoplasm. Clusters of vesicles are often seen along the course of the axon. These vesicles are rather small in number compared with other types of synapses in the molecular layer of the cerebellum. They are characteristically accumulated on one side of the axon. Sometimes well developed membraneous bodies were found, which might suggest the origin or axonal flow of synaptic vesicles along the axon, although evidence was recently given against the axonal flow of protein by Peterson et al. (1967). Concerning the filamentous nature of the axons, it must be taken into consideration that not only the basket cell axons but also climbing fibers are filamentous, which might confuse the identification of the two axon systems. In this point it is fortunate that the latter lacks the membraneous bodies in the axoplasm, so that little difficulty exists in distinguishing these two axons. Furthermore, the following evidence is decisively given for the identification of the two axons. That is, the synapses of the basket cell axon terminals contain flattened vesicles (F-type), while those of the climbing fibers contain spheroid vesicles (S-type). The former is inhibitory, the latter is excitatory according to the author's hypothesis (Uahizono 1965, 1966, 1967 a, b). The F-type synapses at the basket axon terminals which embrace the Purkinje cell soma were described in detail by the author (UGHzoNo 1967). Beside these axon branches there are the ascending branches of basket cell axons which make inhibitory synapses on the dendrites in the molecular layer. Figures 9-A and B, show the case. Here again, the direction of the fiber course, fila-

Fig, 6, A : Parallel fibers in the upper molecular layer. Note the conspicuous parallelism of the granule cell axons. The axoplasm contains membraneous or vesicular structures (arrows) before making synaptic contacts on the spine $(S p)$. Parallel fibers bulge abruptly to make synaptic knobs which contain spheroid vesicles $(S)$. $C$ capillary endothelium.

B : Higher magnification of Figure 6-A. Membraneous or bead-like structures (arrows) are clearly indicated.

Fig. 7. Possible stellate cell axon terminals on the Purkinje dendrite.

A : A F-type synapse $(F)$ on a large, longitudinally sectioned Purkinje cell dendrite $(P d)$ is indicated. Three synapses $\left(S_{1}, S_{2}\right.$ and $\left.S_{3}\right)$ filled with spheroid vesicles and membraneous bodies are shown.

B : Cross-section of a Purkinje dendrite $(P d)$ and various kinds of synapses on the surface of it. Synapse $F_{1}$ is assumed to represent the axon terminal of a stellate cell, while synapse $F_{2}$ is definitely of basket cell origin; the filamentous axoplasm and synaptic vesicles accumulated on one side of the axon characterize the basket cell axon. $S$ S-type synapse. 


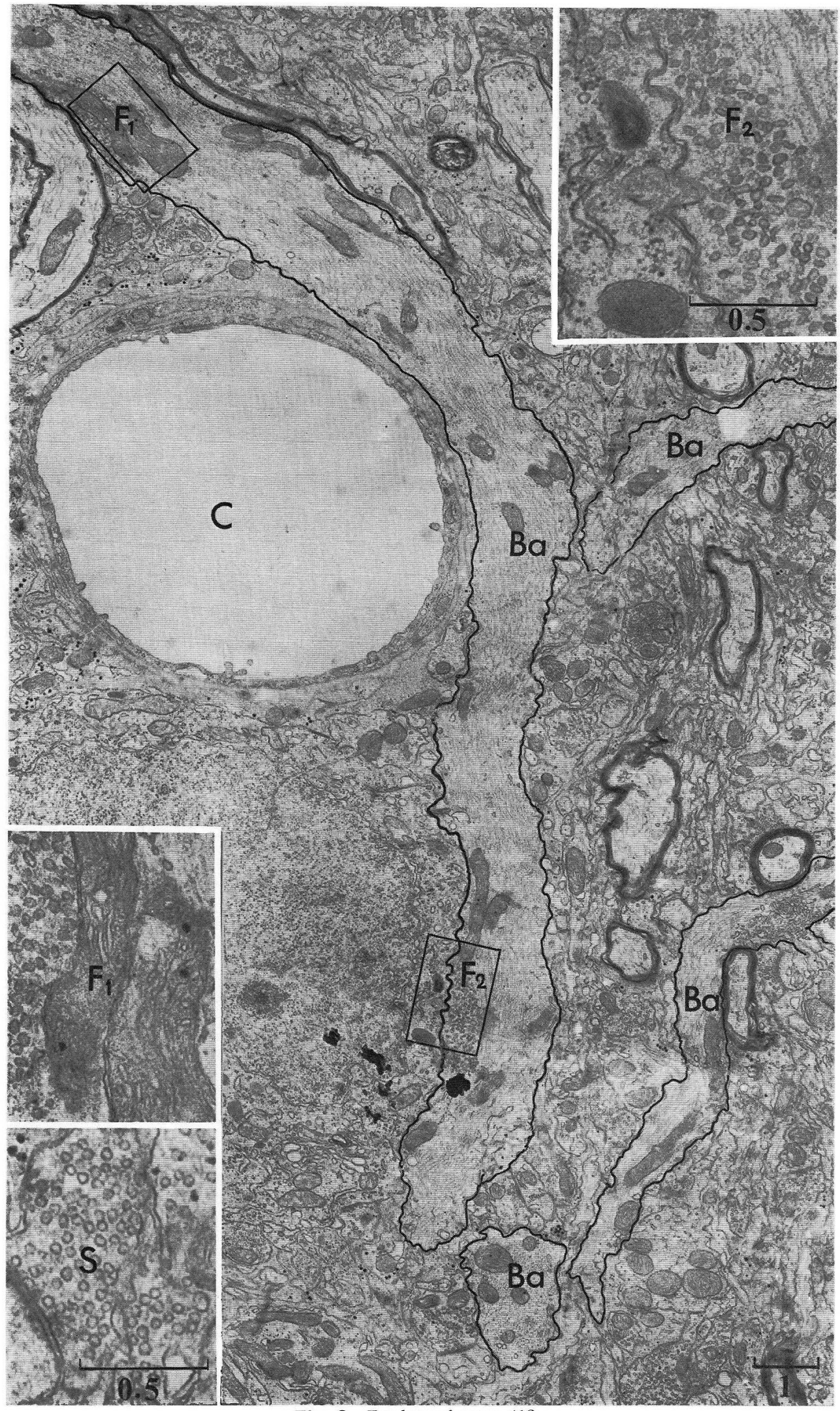

Fig. 8. For legend see p. 413. 
A f.7.

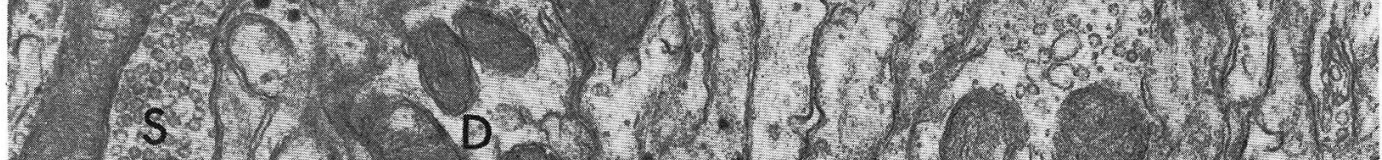

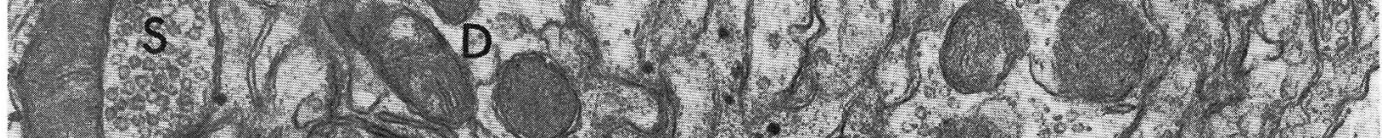

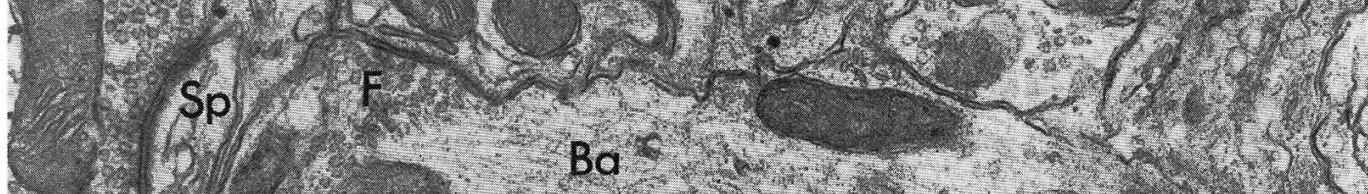

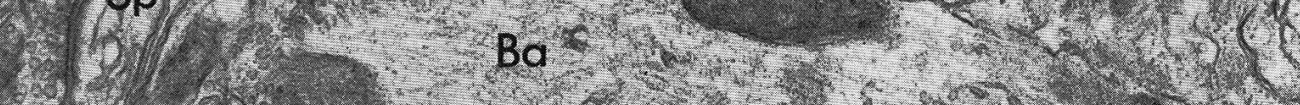

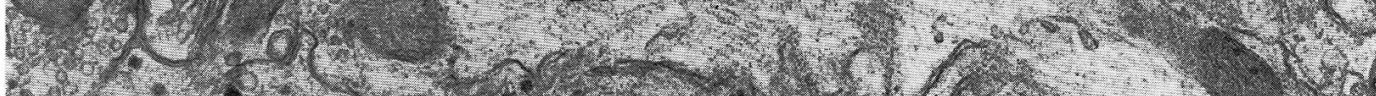
6.

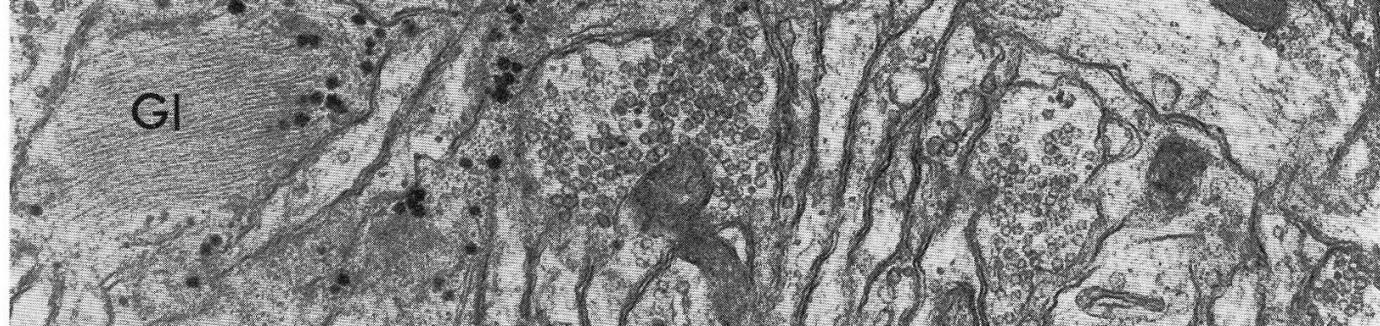

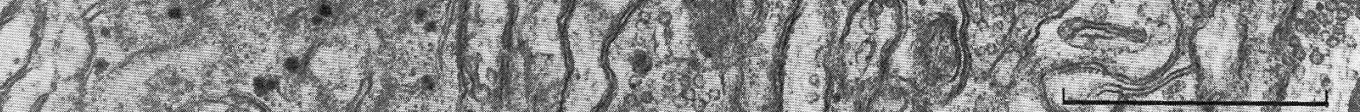

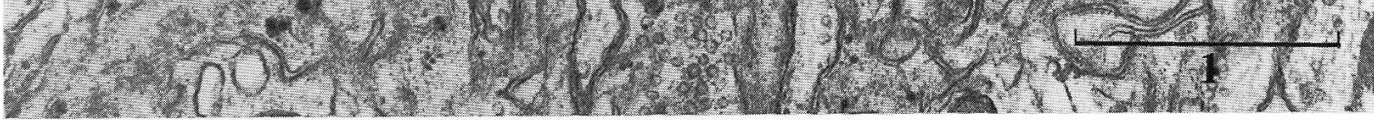

B

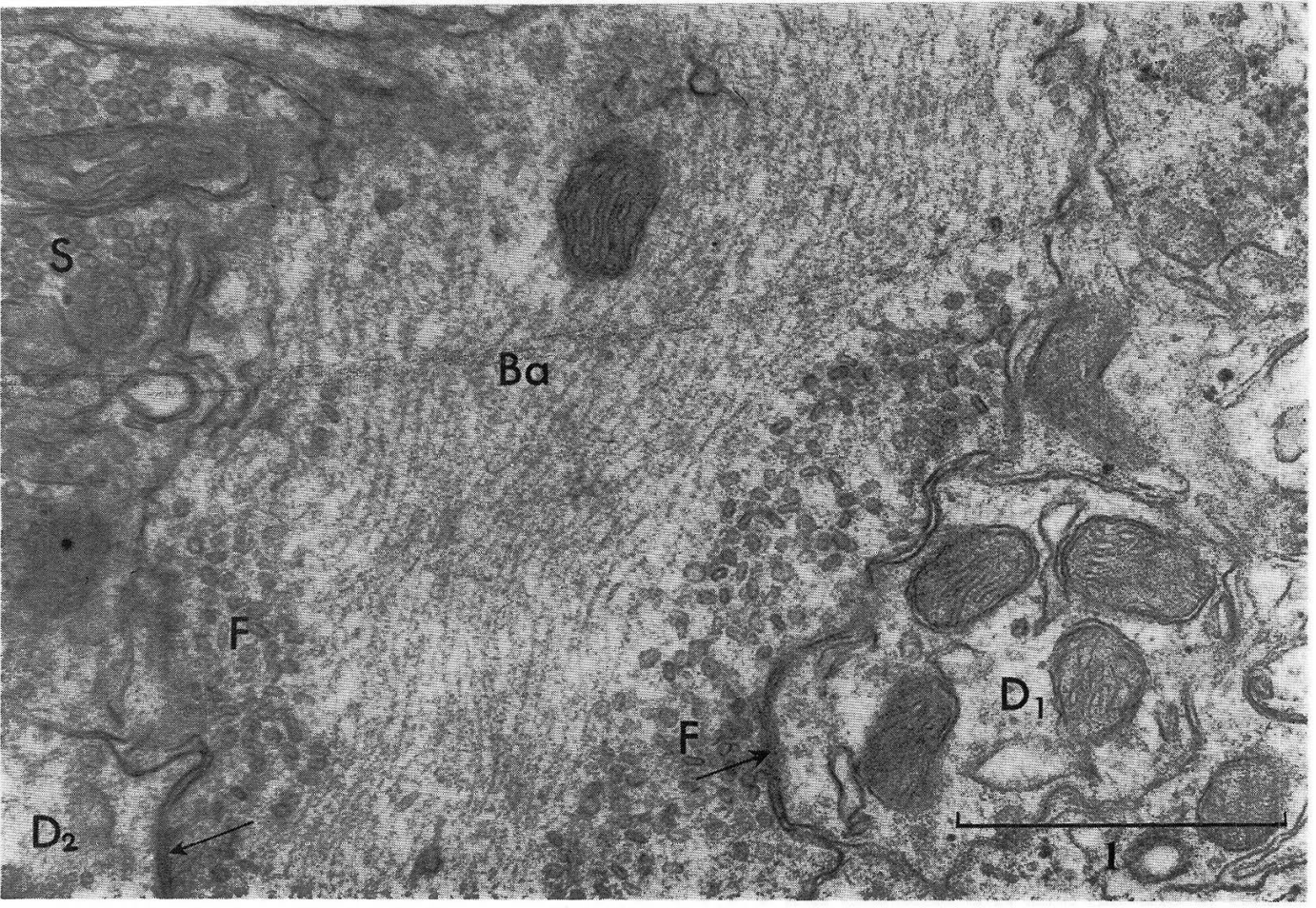

Fig. 9 
mentous axoplasm and a cluster of a small number of flattened vesicles, accumulated on one side of the axon, make the identification of basket axons unequivocal.

Golgi cell axons: Under the light microscope it has been well established that the axon of the typical Golgi neuron arises usually from the base of the cell body, or from a descending dendrite, and immediately begins to arborize in the fashion of Golgi type II axons. The terminal arborization pattern of the Golgi axons was clearly demonstrated by CAJAL (1911), who indicated that it must be involved in the formation of cerebellar glomeruli. Hamori and Szentágothai (1966 b) showed that the individual profiles of the Golgi axons can be seen in a single glomerulus. Therefore it is postulated that they probably all belong to the same axon ramification. This was already suggested from Golgi pictures of CAJAL (1911). The above-mentioned workers attempted to recognize under the electron microscope the terminations of the Golgi axons. They succeeded in identifying the Golgi axons, concluding that the Golgi axons make synapses with the granule cell dendrites or with the mossy fiber rosettes. This was further confirmed by the degeneration experiments of Fox et al. (1967) and Hamori and Szentágothai (1967).

Figure 11 shows a part of a glomerulus of the cat's cerebellum. A large mossy rosette filled with a huge number of spheroid vesicles (S-type) occupies the most part of the space. Small profiles of Golgi cell terminals are seen to invaginate into the mossy fiber rosette. But they do not make any synaptic contact. The synapses of the Golgi cell axons contain flattened vesicles (F-type), while the mossy fiber synapses contain spheroid vesicles (S-type), indicating that the former is inhibitory, the latter excitatory. These findings are in complete agreement with the electrophysiological data obtained mainly by Eccles and his associates (1964, 1966 a, b, c).

It was proved to be difficult to identify the Golgi axons at non-terminal parts of the fibers. So far no definite criteria for the identification of Golgi axons have been established except at the terminal.

Glimbing fibers: It has been well established since the days of CAJAL (1911) that the climbing fibers are of extraneous origin which ascend undivided through the white matter of the cerebellum, eventually to enter and traverse the granule layer. Each climbing fiber attaches itself to a single Purkinje cell and climbs up on the dendritic trees in an ivy-like fashion. Saheibel and Saheibel (1954) carried out an extensive work utilizing their vast amount of Golgi specimens. They emphasized the importance of the side branches of the climbing fibers. CAJAL (1911) already

Fig. 8. Basket cell axons in the supraganglionic plexus of the cerebellar cortex. Long axons $(B a)$ rich in neurofilaments of the basket cell are shown. Accumulation of synaptic vesicles of flattened or F-type to certain areas of the axoplasm is shown in two squares $\left(F_{1}\right.$ and $\left.F_{2}\right)$ which are shown at a higher magnification in the insets. $S$ S-type synapses shown as a control.

Fig. 9. Basket axons in the upper molecular of the cerebellar cortex.

A : Characteristic accumulation of a small number of F-type vesicles to the synaptic site and the axoplasm rich in neurofilaments strongly suggest the basket cell origin of this axon $(B a)$. $D$ dendrite, $S$ S-type synapse, $S p$ spine, $G l$ glial filaments.

B : A basket axon $(B a)$ making two synaptic contacts (arrows) with the dendrites $\left(D_{1}, D_{2}\right)$ at the same time. The flattened nature of the synaptic vesicles $(F)$ is clearly contrasted by the spheroid vesicles in S-type synapses near-by $(S)$. 
A

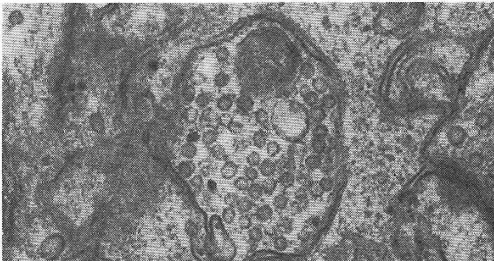

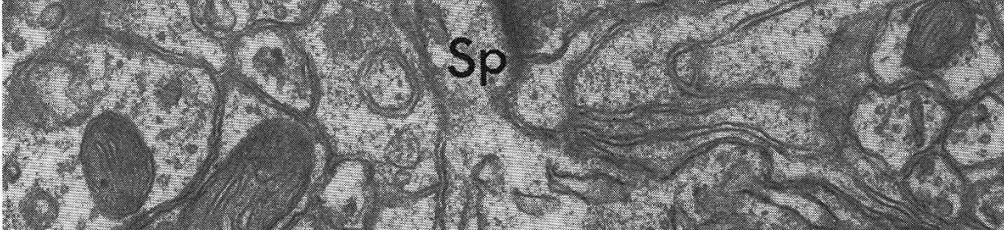

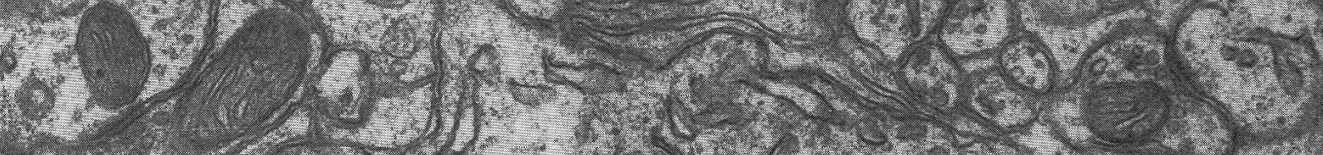

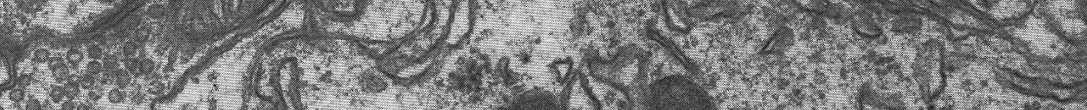

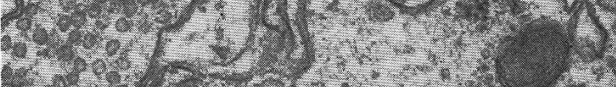

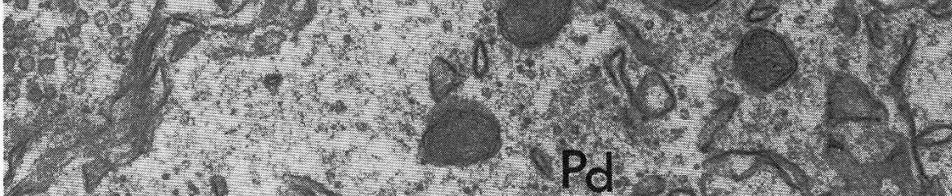

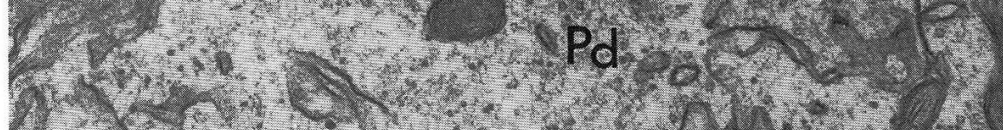

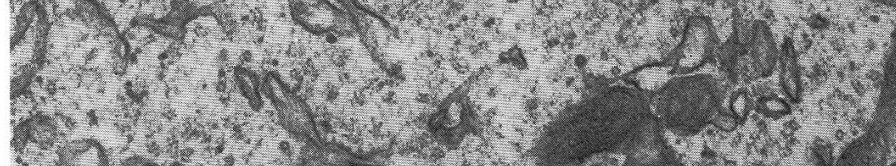

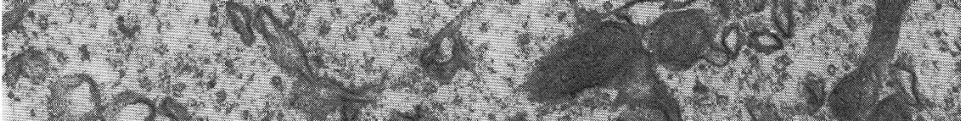

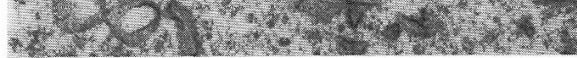

B

-

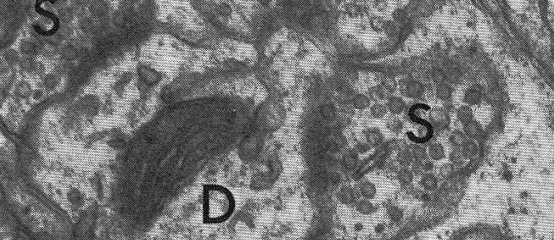

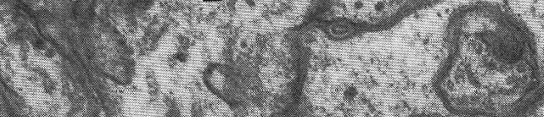

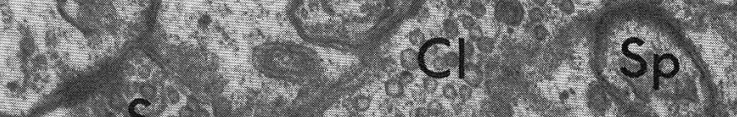
f.

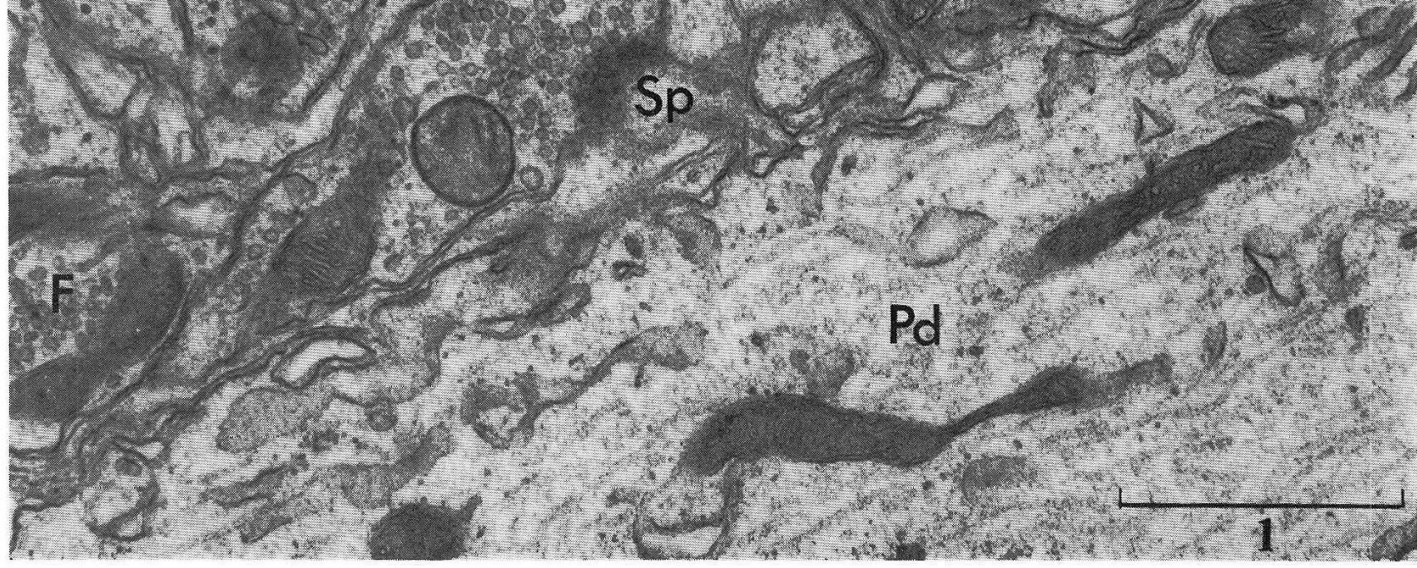


described and illustrated these side branches without paying much attention to the question of whether the climbing fibers establish synaptic contacts with the smooth dendrites of the Purkinje cell along the long course of dendritic trees. It has been reported that its main branches attach themselves to the primary and secondary dendritic trees. Figures $10-\mathrm{A}$ and $\mathrm{B}$ show cross and longitudinal sections of the smooth dendrites of the Purkinje cell.

Climbing fibers go up parallel with the dendrites, therefore, these figures also show the cross and longitudinal sections of climbing fibers. It was pointed out by the author (Uchizono 1967) that the so-called smooth dendrites of the Purkinje cells are, contrary to the classical observations under the light microscope, provided with short-necked spines, which might have escaped the light microscopic identification. Climbing fibers establish synaptic contacts usually on the surface of these spines, using the latter for their scaffoldings. Well developed neurofilaments and spheroid vesicles (S-type) are the principal features of these fibers, confirming electrophysiological findings that the climbing fibers are excitatory in function. As already mentioned, the climbing fibers lack the membraneous bodies in the axoplasm and their synapses contain spheroid vesicles, so that no confusion occurs in distinguishing these fibers from the basket cell axons, because the latter is provided with membraneous bodies in the axoplasm in addition to the flattend vesicles (F-type) and rich neurofilaments. The observations of degenerating climbing fibers have led to the discovery that the descending collaterals described by Saheibel and Saheibel (1954) do not terminate on the granule cells, as the authors presumed, but on the cell bodies of the Golgi, basket and upper stellate cells (Szentágothai and Raikovits 1959). Electron microscopic investigations carried out by HAMORI and SzentágothaI (1966 b) confirmed these results.

Mossy fibers : Miskolazy (1931) was the first to afford reliable information on the origins of mossy fibers from multiple sources. Electron microscopy has established beyond doubt that the mossy fibers have synaptic contacts almost exclusively in the glomeruli. A mossy fiber rosette occupies the central part of the glomerulus (Fig. 12).

If cut longitudinally through the axis, it shows a large sigmoid presynaptic profile which has a central core with abundant neurotubules and clusters of mitochondria. Myelinated mossy fibers lose their sheaths at the axon terminals and bulge abruptly to make large rosettes. From the opposite end of one rosette arises another rosette, again from this arises another one, thus forming a chain of rosettes.

It must be emphasized that the mossy fiber axoplasm is, different from the basket and climbing fibers, rich in neurotubules, but not in neurofilaments. The inset in Figure 12-B shows these abundant neurotubules and a few neurofilaments at the higher magnification. The mossy fiber rosette is covered by numerous postsynap-

Fig. 10. Climbing fiber synapses on the Purkinje cell dendrite.

$\mathbf{A}$ : A cross-section of a Purkinje dendrite $(P d)$ and a climbing fiber synapse $(C l)$ on the surface of a short-necked small spine $(S p)$ of this dendrite.

B : A longitudinal section of a Purkinje cell dendrite $(P d)$ and of a climbing fiber $(C l)$. The latter makes synaptic contacts on the short-necked spines $(S p)$ of the dendrite $(P d)$. A small dendrite $(D)$ of unknown origin is surrounded by three S-type synapses $(S)$. A F-type synapse is indicated at the lower left. 


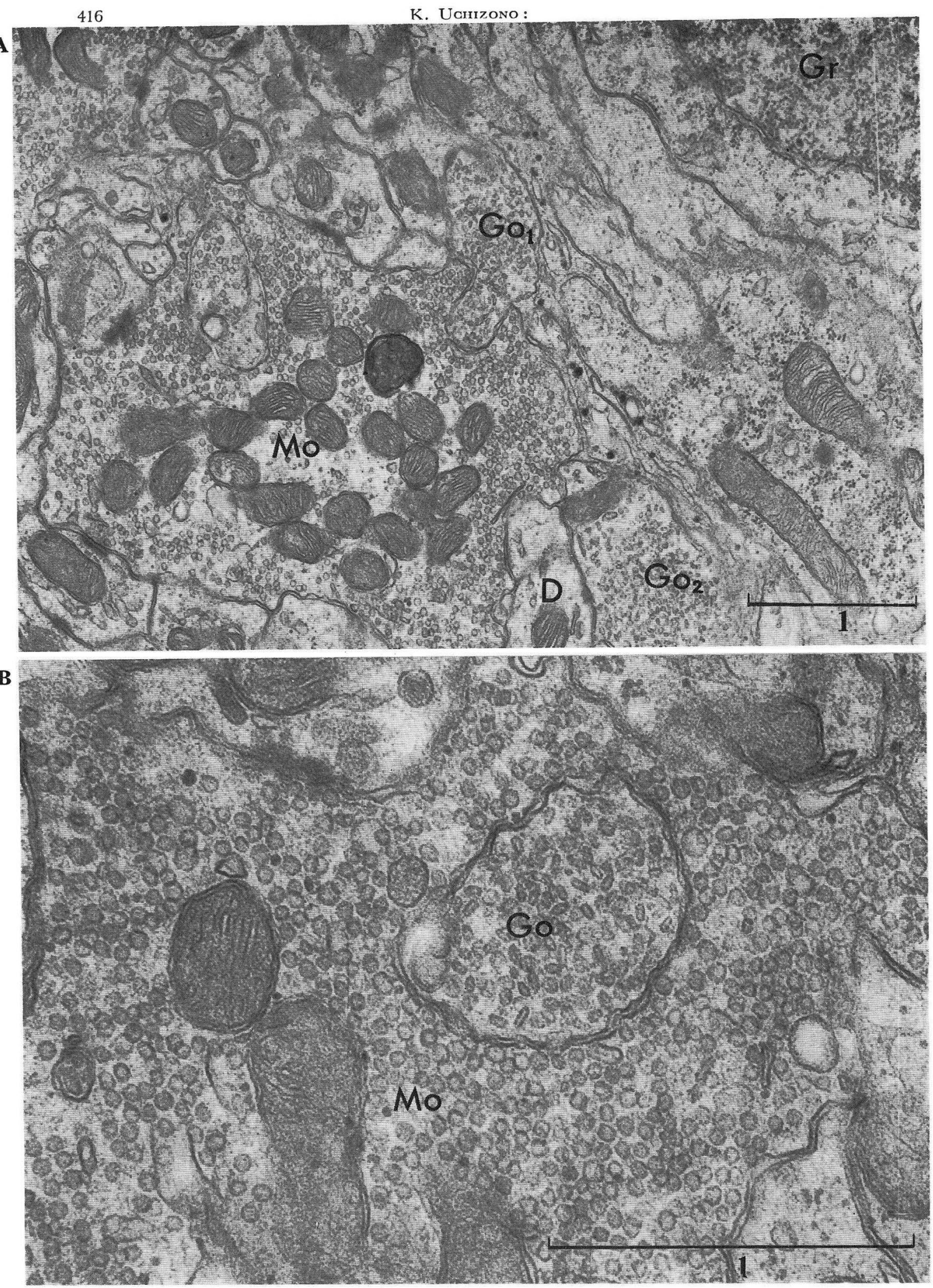

Fig. 11 
tic structures, having spheroid or ovoid profiles which were described by GRAY (1961) as belonging to granule cell dendrites. There are also desmosoid contacts between the dendritic terminals. This was termed by GRAY (1961) a dendritic attachment plaque. Golgi axon terminals were already described by GAJAL (1911) and an attempt to recognize them under the electron microscope was tried by Szentágothai (1962). Quite recently it was established that the descending dendrites of Golgi cells participate in the formation of a glomerulus. Golgi dendrites engage in broad synaptic contacts with mossy rosette. Golgi axons do not form synapses either with the Golgi cell dendrites or with the mossy fiber rosettes (Hamori and Szentágothai $1966 \mathrm{~b})$. Using the technique of the chronically isolated folia or of the chronically deafferented cerebellum, Fox et al. (1967), Hamori and Szentágothai (1966 b) have confirmed that the Golgi terminals are the small beaded axons. These observations fit well with the findings of the present author (Uchizono 1967) who showed that a couple of Golgi cell axons make a cluster of synapses arranged side by side. The fact that the mossy rosette contains spheroid vesicles strongly supports the electrophysiological findings of Ecales and his associates (1964, 1966 a, b, c, d), who established that the former is excitatory, while the latter is inhibitory in function.

Out-pocketing synapses: Sometimes an out-pocketing synapse which was made on the spine of an unknown dendrite was observed in the supraganglionic plexus (Fig. 13). The fiber size (less than $1 \mu$ ) and direction of these small myelinated axons, perpendicular to the parallel fibers, suggest the climbing fiber origin of these axons, although another possibility is also suggested that these myelinated fibers might belong to the mossy fiber, because both climbing and mossy fibers are established to be excitatory in function and their synapses contain spheroid vesicles (S-type). Bodian (1966) reported the same type of an out-pocketing synapse in the

Fig. 11. Axon terminals of the mossy fiber and the Golgi cell.

A : A small profile of Golgi cell axon terminal $\left(G_{1}\right)$ is seen to invaginate into the big synapse of mossy fiber $(M o)$. The mossy fiber synapse is filled with spheroid vesicles and mitochondria. A granule cell dendrite $(D)$ is sandwiched by a synapse of Golgi cell $\left(G_{02}\right)$ and the mossy fiber $(M o)$.

B : Cross-section of a Golgi axon terminal which invaginates into a mossy fiber synapse $(M o)$ is shown at a higher magnification. It is unequivocally indicated that the mossy fiber synapse is of S-type, while that of Golgi cell is of F-type.

Fig. 12, Mossy fiber and cerebellar glomeruli.

A : A longitudinal section of a mossy fiber (Max) with clear axoplasm bulges abruptly to form a synapse $\left(M o_{1}\right)$ filled with spheroid synaptic vesicles. A mossy rosette $\left(M_{02}\right)$ is shown in the center making multiple synaptic contacts (arrows) on the granule cell dendrites $(D)$. Golgi axon terminals of F-type synapse are indicated $(G o)$.

B : Node of Ranvier of a mossy fiber is shown. Myelinated part of the axon $(M y)$ is in the left. The axoplasm is characteristically rich in neurotubules but not in neurofilaments as is shown in the inset at the lower right. Accumulation of spheroid vesicles at the nodal portion of the axon is indicated.

Fig, 13. Out-pocketing synapse at the node of Ranvier of a small myelinated axon in the upper molecular layer of the cerebellar cortex .

A : Small axon (less than $1 \mu$ in diameter) with its thin myelin $(M y)$ makes S-type synapse $(S)$ on the dendrite $(D)$. Parallel fibers $(P f)$ and their synapses $\left(S_{1} \sim S_{3}\right)$ on the spines $(S p)$ are shown.

B : An out-pocketing S-type synapse $(S)$ of a thin myelinated axon is shown at a higher magnification. $M y$ thin myelin sheath, $D$ dendrite. 


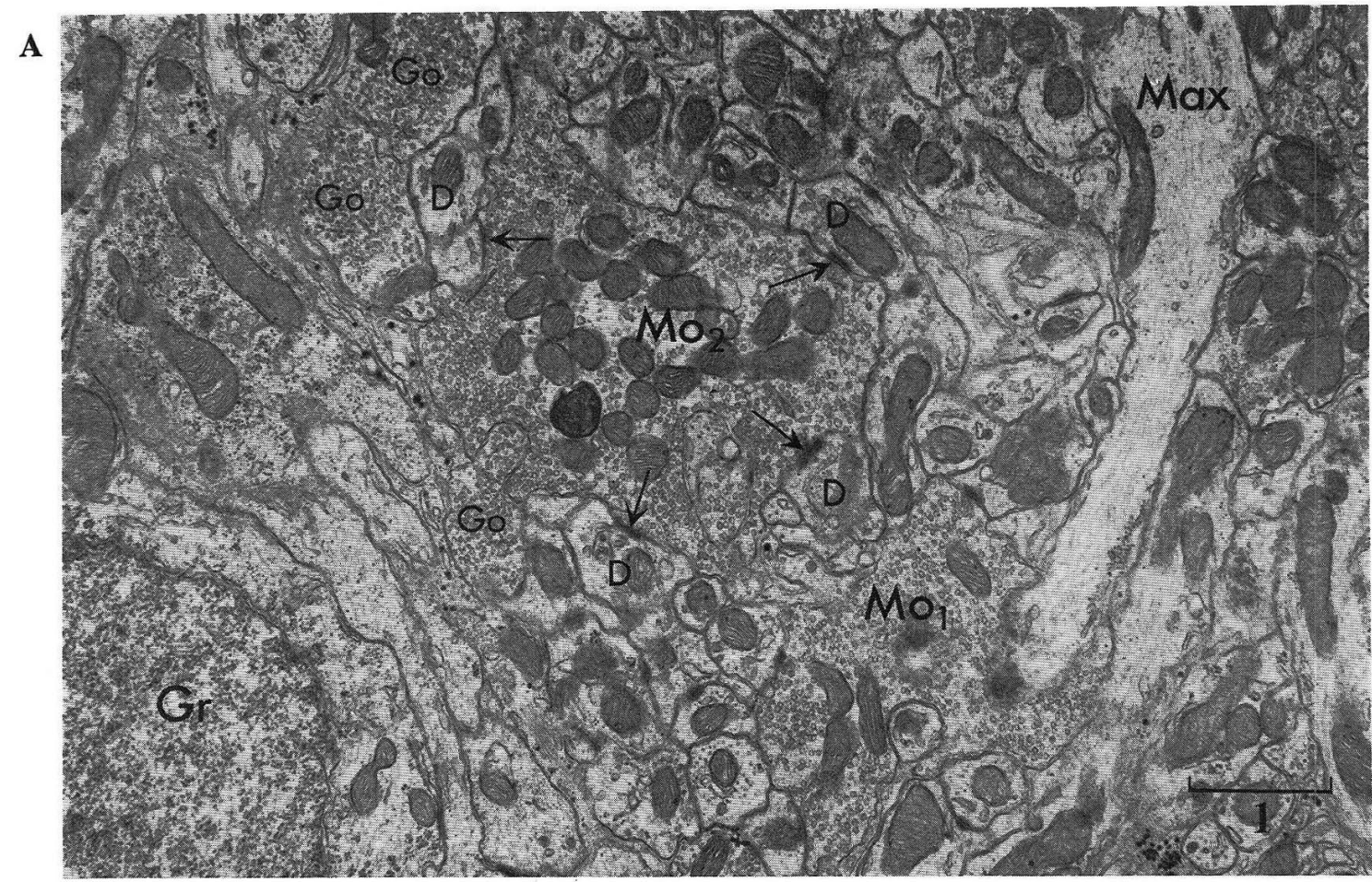

B

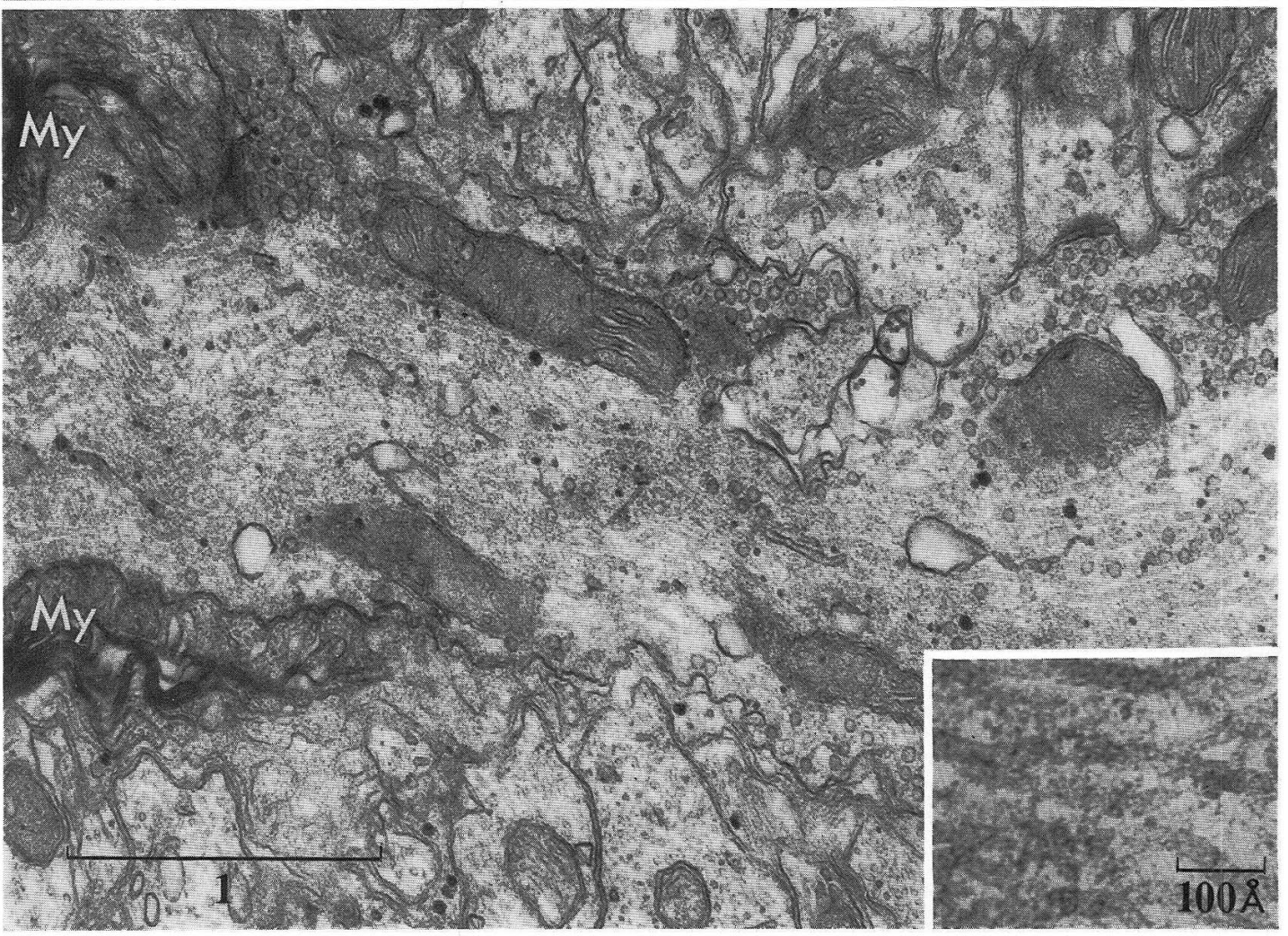

Fig. 12. For legend see p. 417. 
A

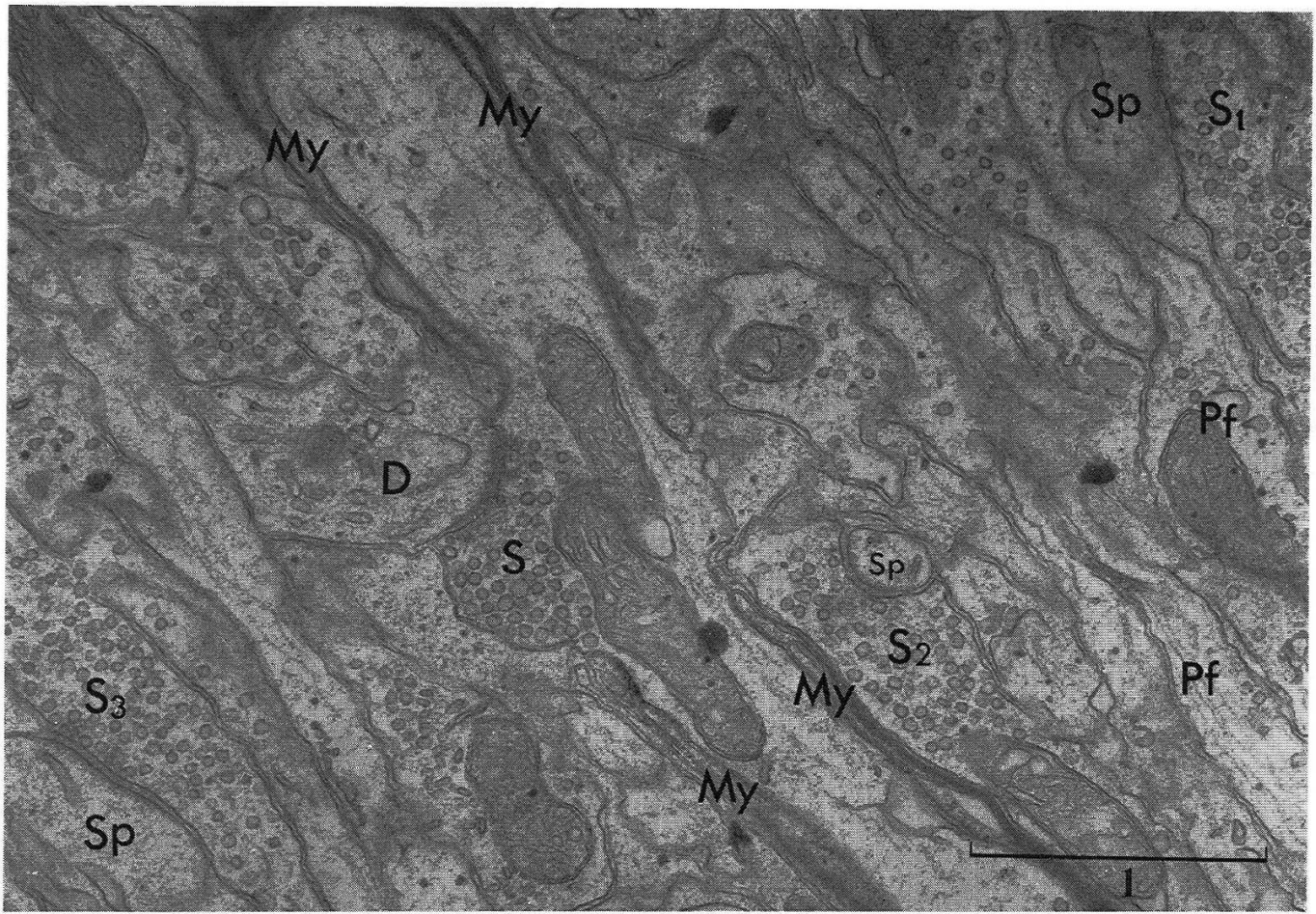

B

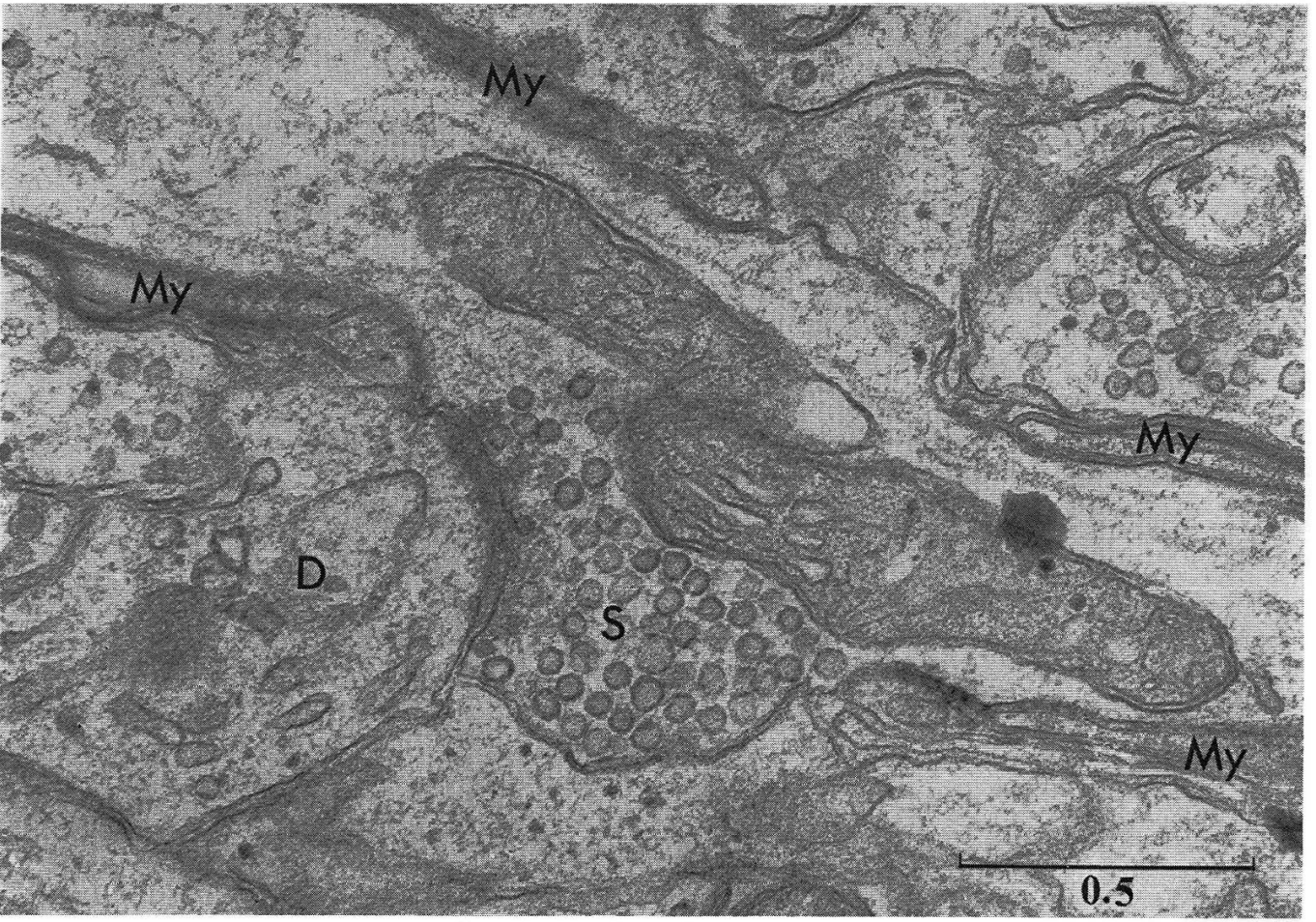

Fig. 13. For legend see p. 417 . 
spinal cord. So-called "climbing fibers" make the same type of synaptic contacts on the dendrite of neurons in the Deiters' nucleus as reported by Mugnaini, Walberg and Haulie Hanssen (1967). The origin of the out-pocketing synapse from the Purkinje cell axon collaterals will be rejected on the ground that these out-pocketing synapses contain always spheroid vesicles, while the axon collaterals of the Purkinje cells make synapses which contain flattened vesicles. Usually the climbing fibers in the upper molecular layer are unmyelinated. It is also improbable that the ascending mossy fibers are still myelinated in this upper part of the cerebellum, because they all lose their myelin at the level of the granule layer when they make cerebellar glomeruli with the Golgi cell axons and granule cell dendrite. Some other unknown origin of this thinly myelinated axons must be looked for.

\section{Discussion}

The axon of the Purkinje cell originates from its lower pole and gradually gets thicker over first $30 \mu$ or so as suggested by Szentágothai (1967), then quite abruptly increases its diameter to normal thickness $(3-5 \mu)$ and becomes myelinated. They proposed that this initial unmyelinated segment be called "pre-axon." The calculated conduction velocity of antidromically activated impulses which was presented by Ecales et al. (1967 a) fits rather well with the value of the measured diameter of the Purkinje axons.

Since the membraneous system has been found in Purkinje axons of the rat by Andres (1965), this can be considered as a general structural property of the Purkinje axons. The problem is that the only a small portion of the whole length of the Purkinje cell axons contains this particular membraneous structure, so its presence is taken as a strong evidence for Purkinje cell origin, but its absence does not always give the negative evidence for the Purkinje axons.

The thin axon of the granule cell takes its origin either from the cell body or more often from one of its dendrites. It ascends to the molecular layer where it bifurcates in T-shape to give rise to the parallel fibers. This short-axoned interneuron is suitable to observe the possible axonal flow of chemical substances from the cell body to the terminal of the axon. An evident figure of axonal flow of synaptic vesicles or their precursors was suggested in the T-shaped branches of the axons.

According to Hamori and Szentágothai (1965) there is no contact between the descending basket axon collaterals and the upper part of the Purkinje cell body. The author (Uahizono 1967), however, reported that the basket cell axons make broad contacts with the Purkinje cell soma, not only at its pre-axonal part (HAmori and Szentágothal, 1967), but also at the upper part of the cell body. Along the whole course of this broad contacts synaptic sites occur repeatedly, although the number of synaptic vesicles was rather small compared with other type of synapses. It is not yet clear whether these contacts have a real physiological significance or not. A powerful inhibitory activity will be exerted upon most effectively at the preaxonal part of the emerging axons. In addition to the descending collaterals contributing to the Purkinje baskets, the basket axons have also ascending collaterals and ascending terminal ramifications. The exact site of the termination of these collaterals has never been recognized under the light microscope or under the electron microscope. It was suggested by this author (Fig. 8) that the ascending collaterals 
make synaptic contacts probably with the small dendrites of the Purkinje cells. Inhibitory synapses were also identified on the surface of smooth Purkinje dendrites. It was postulated that these F-type synapses also originate from the basket axons. Szentágothai (1965) showed that the upper stellate cell dendrites have direct axodendritic synapses that persist in the isolated folium. The present author considers it possible that the ascending basket axon collaterals also make synaptic contacts with the upper stellate cell dendrites, because F-type synapses are identified there.

On the basis of the ramification pattern of their axons, two types of upper stellate cells have been classified under the light microscope. No functional difference has been proposed between these two neurons, although a remarkable difference has been established in the cytoplasm under the electron microscope (Uchizono, unpublished). No clear-cut criterion for the identification of the upper stellate cell axons has been proposed as yet, although it has been established that synapses at the axon terminals of these neurons contain flattened vesicles (F-type). A transitional form of the upper stellate cells has been proposed by GAJAL (1911), which, otherwise similar to type a stellate neuron, has descending branches participating in the pericellular baskets of the Purkinje cell as the ordinary basket cells do. No difference has been established between these two axons under the electron microscope. Under the light microscope it has been established that there is almost no convergence of the Golgi cell axons on a single glomerulus. Many individual profiles of the Golgi axons can be seen in a single glomerulus. It is suggested that they probably belong to the same axon ramification. Under the electron microscope it was revealed that several synapses which evidently originate from the Golgi cells are packed together, forming important synaptic components of glomerulus on the dendrites of the granule cells. Furthermore, they all contain flattened vesicles, indicating that the Golgi cells are inhibitory in function as has been suggested by electrophysiological investigations of EcCles and his associates (1964, $1966 \mathrm{a}, \mathrm{b}, \mathrm{c}, \mathrm{d})$.

Climbing fibers are now known to originate from the inferior olive. Main inputs to the cerebellar cortex from this extraneous source make synaptic contacts on the smooth dendrites of the Purkinje cells. The excitatory nature of these fibers has been established electrophysiologically and electron microscopically. Comparatively well developed neurofilaments and the repeated occurrence of S-type synapses on the short-necked spines of the smooth dendrites of the Purkinje cell are charateristics of this fiber system. The same feature of synaptic contacts of the climbing fibers has been shown recently in the guinea pig by LARRAMENDI (1967). These morphological findings explain the electrophysiological findings that the stimulation of the inferior olive evokes a strange complex depolarization recorded intracellularly.

The mossy fibers are characterized by their specific formation of synapses in the cerebellar glomeruli. They make synapses at the points where they lose their rather thick myelin sheath. The naked axon terminals bulge abruptly to make large mossy rosettes filled with an an enormous number of spheroid vesicles (S-type) which indicate the excitatory nature of this fiber system. Well developed neurotubules are also characteristic of the fibers. Diameters of the mossy fibers range from 3 to $5 \mu$ which fit rather well with the value of electrophysiologically calculated conduction velocity of $30-40 \mathrm{~m} / \mathrm{sec}$. Several extraneous sources for the mossy fibers are known, but it is not yet decided whether all the systems are equally excitatory or not. So far no 
decisive evidence for or against this has been obtained.

\section{Summary}

The recent works of the present author have revealed that, at least in the cat, the excitatory and inhibitory synapses are clearly distinguished by the shape and size of the synaptic vesicles contained in them. A comparative consideration of the electrophysiological and electron-microscopical findings has namely led him to the hypothesis that the excitatory synapses contain spheroid synaptic vesicles of $500 \AA$ in diameter (S-type) whereas the inhibitory synapses contain flattened ones of a smaller size (F-type).

The application of this hypothesis in identifying the different kinds of nerve fibers in the cerebellar cortex of the cat gives the following results :

1. The axon terminals of the Purkinje cells, which are electrophysiologically known as inhibitory neurons, are represented by the synapses of F-type containing flattened vesicles. These fibers are characterized by a conspicuous lamellar structure of the axoplasm in the course.

2. The granule cells are regarded as excitatory neurons, as their axons or parallel fibers contain in their terminals synaptic vesicles of the S-type.

3. The stellate cells are indicated to be of an inhibitory nature as their axon terminals contain F-type synaptic vesicles.

4. The basket cells are inhibitory neurons whose terminal axons embrace the Purkinje cell somata and contain F-type vesicles in their synapses.

5. The axon terminals of the Golgi cells are involved, together with the dendrites of the granule cells and with the axon terminals of the mossy fibers, in the formation of the cerebellar glomeruli. Their synapses contain F-type vesicles indicating the inhibitory nature of these neurons.

6. The climbing fibers go up parallel with the primary or secondary dendrites of the Purkinje cells, making synapses on the short-necked spines of the Purkinje cell dendrites. These synapses contain S-type vesicles in correspondence with the excitatory nature of these fibers established electrophysiologically.

7. The mossy fibers, after entering the granule layer abruptly lose their myelin and swell up in huge synapses. The synaptic vesicles of the S-type contained there indicate the excitatory nature of the fibers.

Acknowledgement. The author wants to thank Mr. E. Kishimoto for his excellent technical help. Thanks are also due to Miss M. NAKAjima.

\section{ネコの小脳皮質の各種神経線維の同定（内容自抄）}

少くともネコの小脳皮質における興奮性シナプスと抑制性シナプスは，その中に含有さ れるシナプス小胞の形と大きさによって 明瞭に区別しうることを 著者は示して来た. す なわち 興奮性シナプスは直径約 $500 \AA$ の球形のシナプス小胞 ( $\mathrm{S}$ 型) を含有し, 抑制性シ ナプスは てれより小さい扁平なシナプス小胞 ( $\mathrm{F}$-型) を含有する.乙の結論は電気生理 学的所見々電子顕微鏡的所見を勘案して提案されたあのである.

今との仮設をネコの小脳皮質の各種神経線維の同定に適用して，次の結論をうることが 
できる。

1.プルキンエ細胞は 電気生理学的に抑制性のニューロンであるてとが知られており, その神経線維終末のシナプスは 扁平な抑制性のシナプス小胞を含有する. 最も特長的な ことは, この線維の axoplasm はその走向の途中で層状構造を示す.

2. 顆粒細胞は興奮性ニューロンで，その軸索突起である平行線維の終末は $\mathrm{S}$ 型のシナ プス小胞を含有する.

3. 星状細胞は抑制性ニューロンで，その神経終末は $\mathrm{F}$ 型のシナプス小胞を含有する.

4. 籠細胞は抑制性ニューロンで, その神経終末はプルキンエ細胞の soma を籠状につ つみ，そのシナプスは $\mathrm{F}$ 型 シナプス小胞を含有する.

5. ゴルジー細胞は抑制性ニューロンで，その神経終末は 顆粒細胞の樹状突起および荅 線維の神経終末と入りまじった複雑な系球体を形成する。ゴルジー細胞のシナプスは F 型 のシナプス小胞を含有する.

6. 登上線維はプルキンエ細胞の一次樹状突起表面の小さなとげ (spines) の上を, 縄梯 子状に登上する。とげの上につくるそのシナプスは $\mathrm{S}$ 型で, 電気生理学的に証明されたて の線維の興奮性の性質をよく示している.

7. 苔線維は顆粒層に入って急に髄鞘を失い，大きくふくれて巨大なシナプスを形成す る. シナプスは $\mathrm{S}$ 型小胞をふくみ，乙の線維が興奮性線維であることを示す.

\section{References}

Andres, K. H: Über die Feinstruktur besonderer Einrichtungen in markhaltigen Nervenfasern des Kleinhirns der Ratte. Z. Zellforsch. 65 : 701-712 (1965).

Bodian, D.: Synaptic types on spinal motoneurons : An electron microscope study. Bull. Johns Hopkins Hosp. 119 : 16-45 (1966).

Eccles, J. G.: Functional meaning of the patterns of synaptic connections in the cerebellum. Perspect. Biol. Med. $8: 289-310$ (1965).

Eccles, J. C, M. Itoh and J. Szentágothai. : The cerebellum as a neuronal machine. New York, Springer Verlag, 1967.

Eccles, J. G , R. Linas and K. Sasaki : Excitation of cerebellar Purkinje cells by the climbing fibers. Nature (Lond.) 203 : 245-246 (1964).

- : Parallel fiber stimulation and the responses induced thereby in the Purkinje cells of the cerebellum. Exp. Brain Res. 1:17-39 (1966a).

Res : $1: 1-16$ (1966b).

: The inhibitory interneurons within the cerebellar cortex. Exp. Brain

: The mossy fiber granule cell relay in the cerebellum and its inhibition by Golgi cells. Exp. Brain Res. 1:82-101 (1966c).

: The excitatory synaptic action of climbing fibers on the Purkinje cells of the cerebellum. J. Physiol. (Lond.) $182: 268-296$ (1966 d).

Fox, C. A, D. E. Hillman, K. A. Siegesmund and C. R. Dutta : The primate cerebellar cortex : A Golgi and electron microscope study. In : (ed. by) C. A. Fox and K. S. Snider: Progress in Brain Research, Vol. 25. Amsterdam-London-New York, Elsevier, 1967.

Gray, E. G.: Granule cells, mossy synapses and Purkinje spines synapses of the cerebellun : Light and electron microscopic observations. J. Anat. (Lond.) $93: 420-433$ (1961).

Hamori, J.: Identification in the cerebellar isles Golgi II axon endings by aid of experimental 
degeneration. In : (ed. by) M. Titlbach : Electron Microscopy, 1964. Proceedings of third European Regional Conference, Prague, Publishing House of Czechoslov. Acad. Sci. 1964. (Vol. B. p. 291-292).

: Modes of termination of recurrent axon collaterals : An electron microscope study. Exp. Brain Res. 1967 (in press).

Hamori, J. and J. Szentágothai : The Purkinje cell baskets. Acta biol. Acad. Sci. Hung. 15 : 465476 (1965).

: "Crossing-over" synapse. An electron microscope study of the molecular layer in the cerebellar cortex. Acta biol. Acad. Sci. Hung. 15: 465-476 (1965).

: Identification under the electron microscope of climbing fibers and their synaptic contacts. Exp. Brain Res. 1:65-81 (1966a).

: Participation of Golgi neurone processes in the cerebellar glomeruli : An electron microscope study. Exp. Brain Res. 2: 35-48 (1966 b).

Itoh, M.: The origin of cerebellar-induced inhibition of Deiters' neurones. I. Monosynaptic inhibition of the inhibitory postsynaptic potentials. Exp. Brain Res. 2:330-349 (1966).

Itoh, M. and M. Yoshida : Cerebellar evoked monosynaptic inhibition of Deiters' neurones. Experientia $20: 515-516$ (1964).

Miskolczy, D.: Über die Endigungsweise der spinocerebellaren Bahnen. Z. Anat. Entw. -gesch. $96: 537-542$ (1931).

Mugnaini, E, G. Walberg and Hauglie-Hanssen: Observations on the fine structure of the lateral vestibular nucleus (Deiters' nucleus) in the cat. Exp. Brain Res. 4:146-186 (1967).

Peterson, R. P. R. M. Furwitz and R. Lindsay : Migration of axonal protein : Absence of a protein concentration gradient and effect of inhibition of protein synthesis. Exp. Brain Res. $4: 138-145$ (1967).

Ramon y Cajal, S.: Histologie du système nerveux de l'homme et des vertébrés. Paris, Maloine, 1911.

Scheibel, M. E. and A. B. Scheibel : Observations on the intracortical relations of the climbing fibers of the cerebellum. J. comp. Neurol. $101: 733-760$ (1954).

Szentágothai, J : Anatomical aspects of junctional transformation. In : (ed. by) R. W. Gerard and J. W. Duyff : Information Processing in the Nervous System. Proc. Int. Union Physiol. Sci., Vol. 3, 33. Int. Congr., Leiden-Amsterdam, Excerpta Medica Foundation, 1962 (p. 119-136)

-: The use of degeneration methods in the investigations of short neuronal connexions. In : (ed. by) M. Singer and J. P. Schade: Progress in Brain Research. Vol. 14 : Degeneration patterns in the nervous system. Amsterdam-London-New York, Elsevier 1965 (p. 1-33).

Szentágothai, J, und K. Rajkovitz: Über den Ursprung der Kletterfasern des Kleinhirns. Z. Anat. Entw.-gesch. 121: 130-141 (1959).

Uchizono, K: Characteristics of excitatory and inhibitory synapses in the central nervous system of the cat. Nature (Lond.) $207: 642-643$ (1965).

- Excitatory and inhibitory synapses in vertebrate and invertebrate animals. Electron Microscopy 2: 431-432. Tokyo, Maruzen, 1966 a.

- Excitatory and inhibitory synapses in the cat spinal cord. Jap. J. Physiol. 16:570-575 (1966).

- : Inhibitory synapses on the stretch receptor neurone of the crayfish. Nature (Lond.) 214 : 833-834 (1967a).

: Synaptic organization of the Purkinje cells in the cerebellum of the cat. Exp. Brain Res. $4: 97-113$ (1967 b). 